\title{
High concentrations of sub-3nm clusters and frequent new particle formation observed in the Po Valley, Italy, during the PEGASOS 2012 campaign
}

\author{
Jenni Kontkanen ${ }^{1}$, Emma Järvinen ${ }^{1,2}$, Hanna E. Manninen ${ }^{1}$, Katrianne Lehtipalo ${ }^{1,3}$, Juha Kangasluoma ${ }^{1}$, \\ Stefano Decesari ${ }^{4}$, Gian Paolo Gobbi ${ }^{5}$, Ari Laaksonen ${ }^{6,7}$, Tuukka Petäjä ${ }^{1}$, and Markku Kulmala ${ }^{1}$ \\ ${ }^{1}$ Department of Physics, 00014 University of Helsinki, Helsinki, Finland \\ ${ }^{2}$ Institute for Meteorology and Climate Research, Karlsruhe Institute of Technology, 76021 Karlsruhe, Germany \\ ${ }^{3}$ Paul Scherrer Institute, 5232 Villigen, Switzerland \\ ${ }^{4}$ Istituto di Scienze dell' Atmosfera e del Clima, CNR, 40129 Bologna, Italy \\ ${ }^{5}$ Institute of Atmospheric Sciences and Climate, CNR, 00133 Rome, Italy \\ ${ }^{6}$ Department of Applied Physics, University of Eastern Finland, 70211 Kuopio, Finland \\ ${ }^{7}$ Finnish Meteorological Institute, 00101 Helsinki, Finland
}

Correspondence to: Jenni Kontkanen (jenni.kontkanen@helsinki.fi)

Received: 25 September 2015 - Published in Atmos. Chem. Phys. Discuss.: 24 November 2015

Revised: 28 January 2016 - Accepted: 9 February 2016 - Published: 19 February 2016

\begin{abstract}
The concentrations of neutral and charged sub$3 \mathrm{~nm}$ clusters and their connection to new particle formation (NPF) were investigated during the PEGASOS campaign (7 June-9 July 2012) at the San Pietro Capofiume measurement station in the Po Valley, Italy. Continuous high concentrations of sub-3nm clusters were detected during the measurement period, although the condensation sink was relatively high (median value $1.1 \times 10^{-2} \mathrm{~s}^{-1}$ ). The median cluster concentrations were 2140 and $7980 \mathrm{~cm}^{-3}$ in the size bins of $1.5-1.8$ and $1.8-3 \mathrm{~nm}$, and the majority of them were electrically neutral. NPF events were observed during the measurement period frequently, on $86 \%$ of the days. The median growth rates of clusters during the events were 4.3, 6.0 and $7.2 \mathrm{~nm} \mathrm{~h}^{-1}$ in the size ranges of $1.5-3,3-7$ and 7$20 \mathrm{~nm}$. The median formation rate of $1.6 \mathrm{~nm}$ clusters was high, $45 \mathrm{~cm}^{-3} \mathrm{~s}^{-1}$, and it exceeded the median formation rate of $2 \mathrm{~nm}$ clusters by 1 order of magnitude. The ion-induced nucleation fraction was low; the median values were $0.7 \%$ at $1.6 \mathrm{~nm}$ and $3.0 \%$ at $2 \mathrm{~nm}$. On NPF event days the neutral cluster concentration had a maximum around 09:00 (local winter time), which was absent on a non-event day. The increase in the cluster concentrations in the morning coincided with the increase in the boundary layer height. At the same time radiation, temperature and $\mathrm{SO}_{2}$ concentration in-
\end{abstract}

creased, and RH and condensation sink decreased. The concentrations of neutral and charged clusters were observed to have a positive correlation with sulfuric acid proxy, indicating the significance of sulfuric acid for the cluster formation in San Pietro Capofiume. The condensation sink had a negative correlation with the concentration of charged clusters but no clear relation to the neutral cluster concentration. This finding, together with back-trajectory analysis, suggests that the precursor vapors of the clusters and background aerosol particles, acting as their sink, have possibly originated from the same sources, including e.g., power plants and industrial areas in the Po Valley.

\section{Introduction}

New particle formation (NPF) is a dominant source of aerosol particles in the atmosphere (Spracklen et al., 2006; Yu et al., 2010). The process takes place by the formation of nanometer-sized atmospheric clusters and their subsequent growth to larger particles (Kulmala et al., 2007, 2013). After that they may affect the climate through indirect radiative effects of aerosol particles (Merikanto et al., 2009; Wang and Penner, 2009; Kazil et al., 2010; Makkonen et al., 2012). 
NPF has been observed around the world in various locations (Kulmala et al., 2004a; Zhang et al., 2012). Although recent chamber studies have provided insight into the role of different chemical compounds in NPF (Kirkby et al., 2011; Almeida et al., 2013; Schobesberger et al., 2013; Riccobono et al., 2014), the exact mechanisms, by which the process takes place in different ambient conditions, are still unknown. The summary of the recent knowledge on physical and chemical processes behind NPF is given by Kulmala et al. (2014).

The relative importance of electrically neutral and charged clusters in atmospheric NPF has been under discussion for decades. Some model studies underline the importance of ions (Yu and Turco, 2000, 2008), while field measurements conducted with ion spectrometers suggest only a minor contribution of ions to NPF in the continental boundary layer (Iida et al., 2006; Kulmala et al., 2007; Manninen et al., 2010) and also higher in the troposphere (Mirme et al., 2010). Recent instrumental development has enabled measuring the concentrations of sub-3nm particles also with condensation particle counters, including a Particle Size Magnifier (PSM; Vanhanen et al., 2011). With these measurement techniques, it has been observed that sub-3nm neutral clusters exist in boreal forest (Lehtipalo et al., 2009; Kulmala et al., 2013), in coastal areas (Lehtipalo et al., 2010), and at high altitude under free tropospheric conditions (Rose et al., 2015). At all these sites, the concentrations of neutral clusters clearly exceed ion concentrations during NPF, which indicates that neutral nucleation mechanisms dominate in these environments. Furthermore, high concentrations of sub-3nm clusters during NPF events have been detected with a PSM at urban sites in the United States (Yu et al., 2014) and at urban, heavily polluted sites in China (Xiao et al., 2015; Yu et al., 2015).

In many of the earlier studies, sub-3nm clusters detected with a PSM have been observed to be associated with elevated sulfuric acid concentration (Kulmala et al., 2013; Yu et al., 2014). This indicates that sulfuric acid is a key compound in the formation of atmospheric clusters, as has been proposed already earlier (e.g., Weber et al., 1997; Sipilä et al., 2010). Sulfuric acid is formed in the atmosphere by the oxidation of sulfur dioxide $\left(\mathrm{SO}_{2}\right)$, which is largely produced in fossil fuel combustion. Therefore, anthropogenic emissions of $\mathrm{SO}_{2}$ may enhance the formation of sub-3nm clusters. On the other hand, high aerosol surface area related to anthropogenic emissions may reduce the sub-3nm cluster concentrations by coagulation (Kerminen et al., 2001; Xiao et al., 2015). Besides sulfuric acid, organic compounds with very low volatility may participate in atmospheric cluster formation (Kulmala et al., 1998; Metzger et al., 2010; Ehn et al., 2014; Schobesberger et al., 2013; Riccobono et al., 2014). These compounds are formed in the atmosphere in the oxidation of VOCs (volatile organic compounds), mainly originating from biogenic sources, such as vegetation (Guenther et al., 2012).

In addition to the concentrations of low-volatile precursor vapors, meteorological conditions may influence the sub- 3nm cluster concentrations. Local meteorology can affect cluster concentrations in several ways. For instance, solar radiation drives oxidation mechanisms forming low-volatile vapors, which, as mentioned above, may participate in the formation of clusters. This is indicated by numerous observations on the importance of solar radiation for NPF (e.g., Boy and Kulmala, 2002; Nieminen et al., 2015). In addition, NPF has been observed to be more favorable in the boundary layer when relative humidity and background aerosol concentrations are low (Hyvönen et al., 2005; Hamed et al., 2011; Nieminen et al., 2015). It has also been proposed that the beginning of NPF may be linked to the onset of turbulence in the boundary layer (Nilsson et al., 2001a). In addition, the origin of air masses has been connected to the probability of NPF events in several locations (Nilsson et al., 2001b; Sogacheva et al., 2007; Nieminen et al., 2015).

In this study, we investigated the concentrations of sub$3 \mathrm{~nm}$ clusters at the San Pietro Capofiume station located in the Po Valley, Italy, during the PEGASOS campaign (7 June9 July, 2012). Previously, NPF events have been found to be frequent in San Pietro Capofiume during summer (Laaksonen et al., 2005; Hamed et al., 2007; Manninen et al., 2010), which may be due to the high emissions of anthropogenic precursor vapors and favorable meteorological conditions. Here, our aim is to further investigate NPF occurring at this site, focusing on the concentrations of sub-3nm clusters and their connection to NPF events. Furthermore, we aim to elucidate the effect of meteorological conditions and the presence of anthropogenic pollutants on the sub-3nm cluster concentrations in San Pietro Capofiume. During the campaign, the concentration of all sub-3nm clusters was measured with a PSM and the concentration of charged clusters with an NAIS (Neutral cluster and Air Ion Spectrometer; Kulmala et al., 2012). From these measurements, we determined the growth rates and formation rates of clusters. We compared the diurnal variation of cluster concentrations and their formation rates to the diurnal evolution of the planetary boundary layer and the variation of different meteorological variables. In addition, we studied how the sulfuric acid concentration and condensation sink, as well as the origin of air masses, affect the concentrations of sub-3nm clusters observed in San Pietro Capofiume.

\section{Measurements and data analysis}

\subsection{Site description and instrumentation}

The measurements took place at the San Pietro Capofiume meteorological station in northern Italy $\left(44^{\circ} 39^{\prime} \mathrm{N}, 11^{\circ} 37^{\prime} \mathrm{E}\right.$; 11 ma.s.1) during 7 June-9 July 2012. The measurements were part of the PEGASOS (Pan-European Gas-AerosolClimate Interaction Study) Zeppelin campaign where San Pietro Capofiume was one of the ground stations. The meteorological station is located about $30 \mathrm{~km}$ northeast of the 


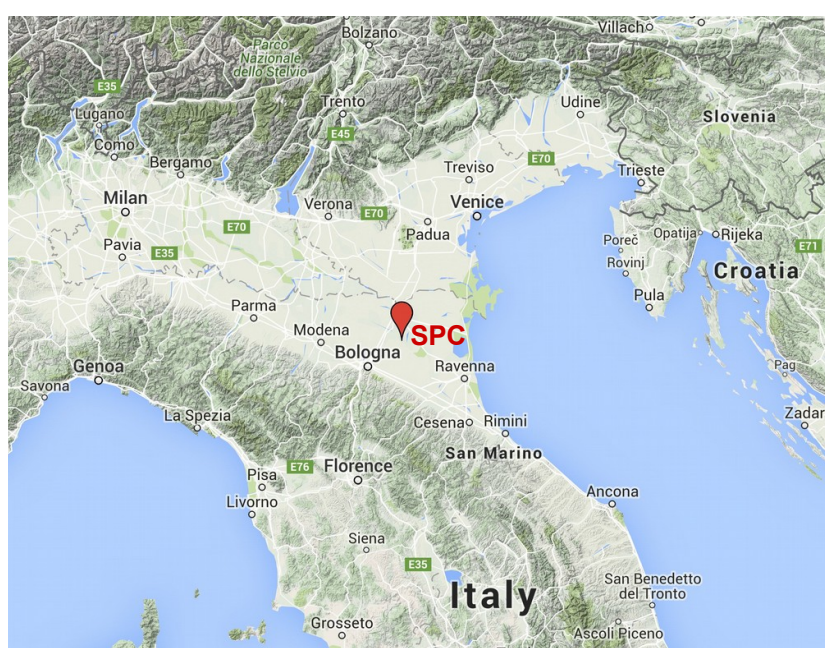

Figure 1. The map of northern Italy, where the location of the San Pietro Capofiume (SPC) measurement site is shown with a red marker. Map data were provided by Google.

city of Bologna in the Po Valley (Fig. 1). The Po Valley region is situated between the Alps in the north and the Apennines Mountains in the south-southwest. The mountains surround the valley on three sides and strongly modify both the local and regional air flow patterns in the area (Sogacheva et al., 2007). High levels of anthropogenic pollutants have been observed in the region due to the emissions from power plants and industrial areas. In addition, the emissions from ship traffic in the Adriatic Sea (Hamed et al., 2007) and longrange transport from central and eastern Europe are possible sources of pollutants in the region (Sogacheva et al., 2007).

During the measurement campaign, the total particle concentrations were measured with an Airmodus Particle Size Magnifier (PSM A09; Vanhanen et al., 2011). PSM is a dualstage mixing-type condensation particle counter. In the first stage, diethylene-glycol is used to activate and grow the particles to about $90 \mathrm{~nm}$ in diameter, after which the further growth and the counting of particles is done with a conventional CPC. The cut-off size of the PSM can be changed by altering the mixing ratio of the sample and saturator flow. In this study, the cut-off sizes of 1.5 and $1.8 \mathrm{~nm}$ were used, and thus, the total concentration of clusters in the size range of $1.5-1.8 \mathrm{~nm}$ was obtained. These cut-off sizes were determined based on laboratory calibrations using ammonium sulfate particles produced in a tube furnace. It needs to be noted, though, that the cut-off size of the PSM has been observed to depend on environmental conditions, especially on relative humidity, and on the composition and the charge of clusters (Kangasluoma et al., 2013; Wimmer et al., 2013). Therefore, the cut-off sizes obtained in the laboratory may not correspond exactly to the cut-off sizes of the instrument in field measurements.

In addition, a twin-DMPS (Differential Mobility Particle Sizer) system was used to measure the number size distribu- tion of particles in the size range of 3-600 nm (Aalto et al., 2001; Laaksonen et al., 2005). By subtracting the concentration measured with the highest cut-off size of the PSM from the total particle concentration measured with the DMPS, we obtained the total concentration of clusters and particles in the size range of $1.8-3 \mathrm{~nm}$. Furthermore, the number size distributions of positive and negative ions between 0.8 and $42 \mathrm{~nm}$ and the number size distributions of all particles between 2 and $42 \mathrm{~nm}$ were measured with a Neutral Cluster and Air Ion Spectrometer (NAIS; Kulmala et al., 2012; Mirme and Mirme, 2013). By interpolating the NAIS data, the ion concentrations in the $1.5-1.8$ and $1.8-3.0 \mathrm{~nm}$ size ranges were obtained. However, the NAIS was not working properly in ion mode during 11-21 June, and therefore this period was excluded from the analysis.

In addition to particle size distribution data, meteorological data, including temperature, relative humidity and global radiation, measured at the station were used in the analysis. The data obtained with a $\mathrm{SO}_{2}$ monitor (model 43i-TLE, Thermo Scientific) were also utilized. Furthermore, the measurement station was equipped with a ceilometer (Jenoptik CHM15K), which allowed us to monitor the evolution of planetary boundary layer (PBL; Di Giuseppe et al., 2012; Angelini and Gobbi, 2014).

\subsection{Determining the concentration of neutral clusters}

To study the importance of ion-mediated processes for cluster formation, we calculated the number of neutral clusters originating from the collisions between oppositely charged ions, i.e., recombination products, in the size bins of 1.5-1.8 and $1.8-3 \mathrm{~nm}$. The concentration of recombination products in size bin $i$ was obtained from Kontkanen et al. (2013):

$N_{\mathrm{rec}, i}=\frac{\lambda_{i} \alpha \sum_{j, k} r_{i j k} N_{j}^{+} N_{k}^{-}}{\operatorname{CoagS}_{i}}$.

Here $\lambda_{i}$ represents the fraction of stable recombination products that do not break up instantly after their formation in size bin $i . \alpha$ is the ion-ion recombination coefficient for which we used the value of $1.6 \times 10^{-6} \mathrm{~cm}^{3} \mathrm{~s}^{-1}$ (Hoppel and Frick, 1986; Tammet and Kulmala, 2005). $N_{j}^{+}$and $N_{k}^{-}$refer to the concentrations of positive and negative ions in size ranges $j$ and $k$, respectively, and $r_{i j k}$ demonstrates how a large fraction of the recombination products formed in their collisions end up in size bin $i$. CoagS $\mathrm{S}_{i}$ is the average coagulation sink for size range $i$. Thus, Eq. (1) takes into account the production of neutral clusters in the collisions between two oppositely charged ions (the term in the numerator) and their loss by coagulation (the term in the denominator). The effect of the condensational growth of clusters was neglected, as has been done in most of the earlier studies discussing the concentrations of recombination products (e.g., Lehtipalo et al., 2009; Kulmala et al., 2013). The production rate of neutral clusters due to ion-ion recombination was calcu- 
lated from the ion size distribution measured with the NAIS. For a detailed description of the procedure, see Kontkanen et al. (2013). The fraction of stable recombination products, $\lambda_{i}$, was assumed to equal unity. The coagulation loss of clusters because of their collisions onto larger aerosol particles was calculated from DMPS data (Kulmala et al., 2001).

After calculating the concentration of recombination products, we calculated the concentration of neutral clusters $\left(N_{\mathrm{n}, i}\right)$, not originating from ion-ion recombination (from now on we refer to these as just neutral clusters), in the size bins of $1.5-1.8$ and $1.8-3 \mathrm{~nm}$ by subtracting the concentrations of ions $\left(N_{\text {ions }, i}\right)$ and recombination products $\left(N_{\text {rec }, i}\right)$ from the total cluster concentration $\left(N_{\mathrm{tot}, i}\right)$ :

$N_{\mathrm{n}, i}=N_{\mathrm{tot}, i}-N_{\mathrm{ions}, i}-N_{\mathrm{rec}, i}$.

For calculating the concentration of neutral clusters from Eq. (2), $10 \mathrm{~min}$ averaged data from the NAIS ( $\left.N_{\text {ions, } i}\right)$, and from the PSM and the DMPS $\left(N_{\mathrm{tot}, i}\right)$, were used.

\subsection{New particle formation event analysis}

The classification of measurement campaign days into new particle formation (NPF) event days and non-event days was done by visually evaluating ion size distribution data from the NAIS (Dal Maso et al., 2005; Hirsikko et al., 2007). The days when new particle formation and growth were observed were classified as NPF event days, while the days with no implication of NPF were assigned as non-event days.

The growth rates of 1.5-3, 3-7 and 7-20 nm particles were determined for the identified NPF events. For calculating the growth rates, we used positive ion size distribution data measured with the NAIS and applied the method by Hirsikko et al. (2005). In this method a Gaussian distribution is fitted to the concentration time series at a certain size to determine the moment of maximum concentration. Then, the growth rate is obtained as the slope of a linear least square fit to the moments of maximum concentrations and the corresponding geometric mean diameters of the particles. For the comparison of particle growth rates determined using different instruments and methods, see Yli-Juuti et al. (2011).

The total particle formation rates and ion formation rates at $1.6 \mathrm{~nm}\left(J_{1.6}\right)$ and at $2 \mathrm{~nm}\left(J_{2}\right)$ were calculated following the method in Kulmala et al. (2012). When calculating the total particle formation rate, we determined the time derivative of particle concentration and took into account the effects of coagulation loss and the growth out of the studied size range. The accuracy of this method is evaluated in Korhonen et al. (2011). When determining the ion formation rate, the loss of ions by ion-ion recombination and the charging of neutral particles were also included in the calculation. The total particle formation rate at $1.6 \mathrm{~nm}$ was determined from the PSM data, while for calculating the total particle formation rate at $2 \mathrm{~nm}$ we used NAIS particle size distribution data. The ion formation rates were calculated from the NAIS ion size distributions. For the growth rates needed for the calcu- lations, we used the growth rates determined for $1.5-3 \mathrm{~nm}$ size range from the NAIS data. However, it needs to be noted that the growth rates of neutral and charged clusters may not be equal in reality, as the presence of charge may enhance the growth of particles (e.g., Yu and Turco, 2000; Nadykto and Yu, 2003).

\subsection{Sulfuric acid proxy}

To study the connection between the concentrations of sub3 nm clusters and sulfuric acid, we calculated the sulfuric acid concentration from a nonlinear statistical proxy derived by Mikkonen et al. (2011):

$$
\begin{aligned}
& \mathrm{SA}_{\text {proxy }}=8.21 \times 10^{-3} \times k \times \mathrm{Rad} \times\left[\mathrm{SO}_{2}\right]^{0.62} \\
& \times(\mathrm{CS} \times \mathrm{RH})^{-0.13} .
\end{aligned}
$$

Here $k$ describes the reaction rate coefficient, which depends on air temperature and atmospheric pressure. Rad refers to global radiation, $\left[\mathrm{SO}_{2}\right]$ to the concentration of sulfur dioxide and RH to relative humidity. CS is the condensation sink that we calculated from the particle size distributions measured with the DMPS, assuming that the condensing vapor is sulfuric acid, and correcting for the hygroscopic growth of particles (Kulmala et al., 2001; Laakso et al., 2004). The proxy was calculated only for times when global radiation exceeded $10 \mathrm{~W} \mathrm{~m}^{-2}$. Mikkonen et al. (2011) concluded that their proxy is suitable for estimating sulfuric acid concentration in a wide range of environmental conditions. Still, as there were no measurements of sulfuric acid concentration during our measurement campaign, the accuracy of the proxy in these specific conditions could not be assessed.

\subsection{Trajectory analysis}

To investigate the origin of air masses during the measurement campaign, we calculated $24 \mathrm{~h}$ backward trajectories using the HYSPLIT (Hybrid Single-Particle Lagrangian Integrated Trajectory) model (Draxler and Rolph, 2015). Global FNL (Final) meteorological archive generated by the NCEP GDAS (National Centers for Environmental Prediction Global Data Assimilation System) were used in the calculations. For each day we studied trajectories arriving at the measurement site hourly between 10:00 and 14:00 local winter time (UTC $+1 \mathrm{~h}$ ) with the arrival height of $100 \mathrm{~m}$. We determined the arrival direction of the air mass by dividing the trajectories into $22.5^{\circ}$ sectors. If a trajectory spent over $70 \%$ of the last $24 \mathrm{~h}$ before arriving to San Pietro Capofiume in a certain sector, that sector was selected to correspond to the arrival direction of the air mass. 

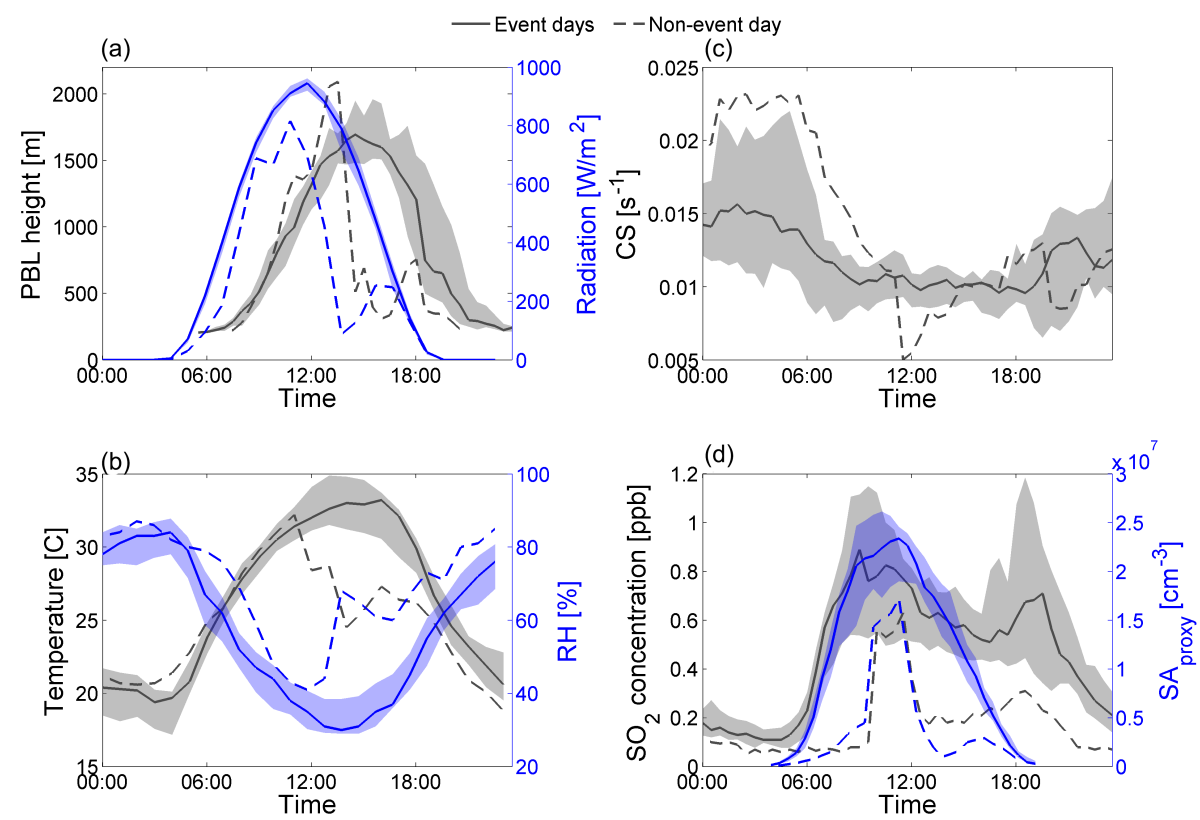

Figure 2. The diurnal variation of different variables during the measurement campaign: (a) PBL height (grey) and global radiation (blue), (b) temperature (grey) and relative humidity ( $\mathrm{RH}$; blue), (c) condensation sink (CS), (d) $\mathrm{SO}_{2}$ concentration (grey) and sulfuric acid proxy (SA proxy; blue). The median diurnal pattern on NPF event days is shown as solid lines, and the 25th to 75th percentile range as the shaded area. The diurnal variation on the only non-event day (6 July 2012) is shown as dashed lines. Time is UTC $+1 \mathrm{~h}$.

\section{Results and discussion}

\subsection{Meteorological conditions in San Pietro Capofiume during the PEGASOS campaign}

The weather conditions during the campaign were initially characterized by moderate instability (from 8 to 14 June), which was followed by a series of sunny, hot days, with relative humidity $(\mathrm{RH})$ decreasing from day to day. The mean temperature for the campaign $\left(25.5^{\circ} \mathrm{C}\right)$ was $3.5^{\circ} \mathrm{C}$ higher compared to a 15-year climatology for the site (data from the Regional Agency for Environmental Protection, ARPA, of Emilia-Romagna). The average RH was $16 \%$ lower than is typical, and the cumulated rain $(24 \mathrm{~mm})$ was half of the expected amount. In summary, the ambient conditions during the experiment were more representative for a heat-wave period than for an average summer in the Po Valley.

The meteorological conditions prevailing during the campaign resulted in the strong diurnal variation of radiation, temperature and RH. The diurnal cycles of these variables are presented in Fig. 2 for new particle formation (NPF) event days ( $86 \%$ of the days, see Sect. 3.3) and the only non-event day (6 July 2012) in local winter time (UTC $+1 \mathrm{~h}$ ). For NPF event days the median diurnal cycle and the 25 th to 75 th percentile range are shown. On NPF event days, global radiation typically started to increase around 04:00, and reached its maximum (median value $940 \mathrm{~W} \mathrm{~m}^{-2}$ ) at noon (Fig. 2a). Temperature began to increase from its nighttime values (about $20^{\circ} \mathrm{C}$ ) at the same time as the radiation and was high- est (about $33^{\circ} \mathrm{C}$ ) around 15:00 (Fig. 2b). The diurnal cycle of $\mathrm{RH}$ was opposite to that of temperature: $\mathrm{RH}$ was highest (about $84 \%$ ) early in the morning and lowest (about 30\%) in the afternoon (Fig. 2b). On the non-event day, global radiation increased in the morning slightly slower than on event days, and after reaching its maximum $\left(820 \mathrm{~W} \mathrm{~m}^{-2}\right)$ around noon, the radiation level dropped rapidly. Correspondingly, temperature also decreased in the afternoon, being $6-8{ }^{\circ} \mathrm{C}$ lower than on NPF event days at that time. On the other hand, in the morning of the non-event day, temperature was similar, or even slightly higher, than on event days. Furthermore, starting from 06:00, RH was higher on the non-event day than on event days, exceeding $60 \%$ in the afternoon. The results support previous studies from San Pietro Capofiume where NPF events have been observed to occur on days with high solar radiation and low RH (Hamed et al., 2007; Sogacheva et al., 2007).

Figure 2a also presents the diurnal variation of PBL height. On NPF event days the progressive increase of the mixing layer from about 250 to $1700 \mathrm{~m}$ can be observed between 07:00 and 15:00. Therefore, the first steps of the photochemical processes observed at the station were triggered by reactions occurring in a rather thin atmospheric surface layer. Conversely, in the late morning and in the afternoon hours, the thickness of the PBL was great enough to allow the entrainment of air masses with their burden of chemical compounds traveling over long distances. On the non-event day, the PBL height increased higher than on event days, reaching about $2000 \mathrm{~m}$. However, similar to radiation, the PBL height 
quickly decreased in the afternoon, being about $1000 \mathrm{~m}$ lower than the PBL height on event days at that time. Further analysis of ceilometer data reveals that low-level clouds were present in the morning and rainfall occurred between 14:00 and 15:00 on the non-event day, which explains the observed behavior of radiation, $\mathrm{RH}$ and the PBL height.

The effect of PBL height on background aerosol concentrations can be seen in the median diurnal variation of condensation sink (Fig. 2c). Condensation sink was highest around 02:00 when the boundary layer was still thin. The maximum value of condensation sink was higher on the nonevent day $\left(0.023 \mathrm{~s}^{-1}\right)$ than on NPF event days (median value $0.015 \mathrm{~s}^{-1}$ ). During the early morning, when the PBL started to form, condensation sink rapidly decreased and around 09:00 reached its daytime level (about $0.01 \mathrm{~s}^{-1}$ both on NPF event days and on the non-event day). During the day, when the mixing layer extended higher in the atmosphere, condensation sink stayed low, and started to increase again after 18:00. Our observation on the lower condensation sink in the mornings of NPF event days compared to the non-event day is consistent with Hamed et al. (2007), who showed that low condensation sink favor particle formation in San Pietro Capofiume.

The diurnal patterns of $\mathrm{SO}_{2}$ concentration and sulfuric acid proxy were also slightly different on NPF event days and on the non-event day (Fig. 2d). On event days $\mathrm{SO}_{2}$ concentration started to rise from its low nighttime values (median value $0.13 \mathrm{ppb}$ ) around 05:00, reaching its maximum (about $0.9 \mathrm{ppb}$ ) around 09:00. After that, $\mathrm{SO}_{2}$ concentration decreased until it showed a second peak (about $0.8 \mathrm{ppb}$ ) around 20:00. The low concentration of $\mathrm{SO}_{2}$ at night is likely due to its deposition on the ground in the nocturnal boundary layer, while the increase in the morning is induced by the mixing of the boundary layer, allowing the entrainment of $\mathrm{SO}_{2}$ from aloft. On the non-event day, $\mathrm{SO}_{2}$ concentration was clearly lower throughout the day than on event days. The increase in the concentration occurred later than on event days (around 10:00), and the concentration reached only about $0.6 \mathrm{ppb}$. The second peak in the evening was also clearly lower (about $0.3 \mathrm{ppb}$ ) than on event days. The diurnal cycle of sulfuric acid proxy on NPF event days resembles the diurnal cycle of radiation; the concentration started to increase around 04:00 in the morning and was highest (median value $2.3 \times 10^{7} \mathrm{~cm}^{-3}$ ) around noon. On the non-event day, sulfuric acid proxy stayed lower than on event days, its maximum value being about $1.7 \times 10^{7} \mathrm{~cm}^{-3}$. In addition, the value of the proxy started to increase later than on event days, reflecting the late increase in $\mathrm{SO}_{2}$ concentration. These results are in agreement with Hamed et al. (2006), who observed that in San Pietro Capofiume, daytime $\mathrm{SO}_{2}$ concentrations are clearly higher on NPF event days than on non-event days.

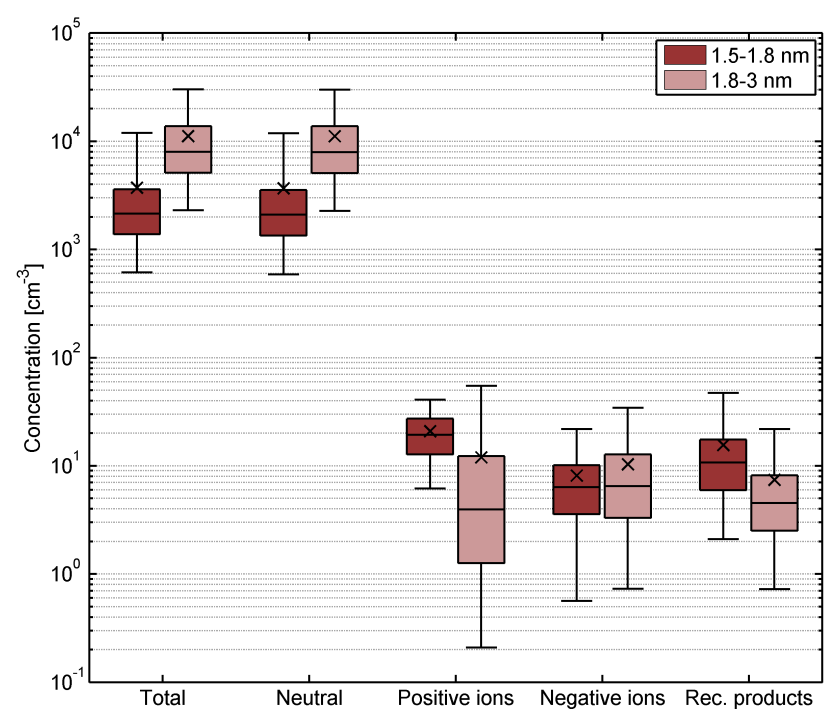

Figure 3. The median concentration of all clusters, neutral clusters, positive ions, negative ions and recombination products in the two size bins (1.5-1.8 and 1.8-3.0 nm). The edges of the boxes show the 25 th and 75 th percentiles and the centers of the boxes represent the median values. The mean values are presented with black crosses. The error bars show the 5th and 95th percentile values.

\subsection{Concentrations of sub-3nm clusters}

A high number of sub-3nm clusters was observed in San Pietro Capofiume during the measurement period (Fig. 3). The total concentration of $1.5-1.8 \mathrm{~nm}$ clusters varied from 610 to $11930 \mathrm{~cm}^{-3}$ (5th and 95th percentile), with a median concentration of $2140 \mathrm{~cm}^{-3}$. The total concentration of $1.8-3.0 \mathrm{~nm}$ clusters varied from 2300 to $30150 \mathrm{~cm}^{-3}$ (5th and 95 th percentile), while the median concentration was $7980 \mathrm{~cm}^{-3}$. The majority of the observed sub-3nm clusters were electrically neutral. The median concentrations of neutral clusters were 2090 and $7950 \mathrm{~cm}^{-3}$ in the size bins of $1.5-1.8$ and $1.8-3 \mathrm{~nm}$, respectively. The median positive ion concentrations were 20 and $4 \mathrm{~cm}^{-3}$ in the same size bins, and the median negative ion concentration was $6 \mathrm{~cm}^{-3}$ in both of the size bins. The concentrations of recombination products were low: the median concentrations were 11 and $5 \mathrm{~cm}^{-3}$ in the size bins of $1.5-1.8$ and $1.8-3 \mathrm{~nm}$. The observed lower concentration of negative $1.5-1.8 \mathrm{~nm}$ ions compared to positive ions is mainly caused by the lower sensitivity of the negative polarity of NAIS to detect these ions, which results from slightly higher electrometer noise levels in corresponding channels. On the other hand, the lower negative ion concentration can also be partly related to the electrode effect, causing the accumulation of positive ions close to the Earth's surface (Hoppel, 1967).

Our results are in agreement with the earlier measurements from boreal forest in Finland, where a continuous population of sub-3nm neutral clusters was observed (Lehtipalo et al., 
Table 1. Growth rates of particles during NPF events. The median values and the range from the 5 th to 95 th percentile are shown. The growth rates were determined from the positive ion size distributions measured with the NAIS.

\begin{tabular}{ll}
\hline Size range & Growth rate $\left(\mathrm{nm} \mathrm{h}^{-1}\right)$ \\
\hline $1.5-3.0 \mathrm{~nm}$ & $4.3(1.0-10.0)$ \\
$3.0-7.0 \mathrm{~nm}$ & $6.0(2.6-12.9)$ \\
$7.0-20.0 \mathrm{~nm}$ & $7.2(3.8-13.8)$ \\
\hline
\end{tabular}

2009; Kulmala et al., 2013). However, the concentrations of clusters observed in San Pietro Capofiume are about 5 times higher than the concentrations in the same size range in boreal forest. The observed cluster concentrations also exceed the concentrations of sub- $3 \mathrm{~nm}$ clusters reported from a highaltitude site in France (Rose et al., 2015) and from two urban sites in the United States (Yu et al., 2014). On the other hand, at polluted sites in China, the sub-3nm cluster concentrations were observed to be of the same order of magnitude as in San Pietro Capofiume (Xiao et al., 2015; Yu et al., 2015). This indicates that the formation of sub-3nm clusters may be favored in areas where anthropogenic emissions of precursor vapors are high. Furthermore, our results support the earlier observations from boreal forest, where the contribution of ion-ion recombination to atmospheric cluster formation has been shown to be minor (Lehtipalo et al., 2009; Kontkanen et al., 2013).

\subsection{New particle formation}

NPF events were frequently observed during the measurement campaign (see Fig. 4). During the measurement period $86 \%(19 / 22)$ of the days, from which we had NAIS data, were classified as NPF event days, while only 1 day was classified as a clear non-event case. On average, NPF is detected at the site less frequently, on $40-45 \%$ of the days in June and on $65-70 \%$ of days in July (Hamed et al., 2007; Manninen et al., 2010). A high frequency of NPF events during our measurement campaign was likely related to favorable meteorological conditions with high solar radiation and low RH (see Sect. 3.1). Figure 5 shows the evolution of ion size distribution on a typical NPF event day (28 June) during the measurement campaign. The onset of an NPF event can be observed around 07:00 and the growth of the ions can be followed until 17:00.

The statistics of particle growth rates for the NPF events are shown in Table 1 . The median growth rates in the size ranges of $1.5-3,3-7$ and $7-20 \mathrm{~nm}$ were $4.3,6.0$ and $7.2 \mathrm{~nm} \mathrm{~h}^{-1}$. Thus, the growth rate generally increased with the increasing particle size, which has also been observed at other measurement sites (Yli-Juuti et al., 2011; Kuang et al., 2012; Kulmala et al., 2013), and predicted by the so-called nano-Köhler theory describing the activation of nanometersized clusters by organic vapors (Kulmala et al., 2004b).
Table 2. The formation rates of all clusters and ions during NPF events. The median values and the range from 5 th to 95 th percentile are shown. The formation rates of all clusters at $1.6 \mathrm{~nm}$ were determined from PSM data. The formation rates of ions at $1.6 \mathrm{~nm}$ and all clusters and ions at $2 \mathrm{~nm}$ were determined from NAIS data.

\begin{tabular}{lll}
\hline Size & Clusters & Formation rate $\left(\mathrm{cm}^{-3} \mathrm{~s}^{-1}\right)$ \\
\hline $1.6 \mathrm{~nm}$ & All clusters & $45(23-53)$ \\
$1.6 \mathrm{~nm}$ & Positive ions & $0.19(0.09-0.32)$ \\
$1.6 \mathrm{~nm}$ & Negative ions & $0.06(0.03-0.08)$ \\
$2.0 \mathrm{~nm}$ & All clusters & $6.8(2.7-38.5)$ \\
$2.0 \mathrm{~nm}$ & Positive ions & $0.12(0.05-0.25)$ \\
$2.0 \mathrm{~nm}$ & Negative ions & $0.08(0.03-0.19)$ \\
\hline
\end{tabular}

By using BSMA (Balanced Scanning Mobility Analyzer) measurements, Manninen et al. (2010) obtained a median growth rate of $1.5 \mathrm{~nm} \mathrm{~h}^{-1}$ for $1.5-3 \mathrm{~nm}$ particles in San Pietro Capofiume. The lower value of median growth rate compared to our results is likely caused by the fact that most of the events for which Manninen et al. (2010) were able to determine the sub-3nm growth rate occurred in spring, when the production of condensable vapors is typically lower than in summertime.

Table 2 presents the statistics of particle formation rates at 1.6 and at $2 \mathrm{~nm}$ during NPF events. The median formation rate of $1.6 \mathrm{~nm}$ clusters, $45 \mathrm{~cm}^{-3} \mathrm{~s}^{-1}$, was 1 order of magnitude higher than the median formation rate of $2 \mathrm{~nm}$ clusters, $6.8 \mathrm{~cm}^{-3} \mathrm{~s}^{-1}$. In earlier field measurements in boreal forest, Finland, the median particle formation rates were $5.9 \mathrm{~cm}^{-3} \mathrm{~s}^{-1}$ at $1.5 \mathrm{~nm}$ and $1.9 \mathrm{~cm}^{-3} \mathrm{~s}^{-1}$ at $2 \mathrm{~nm}$ (Kulmala et al., 2013). On the other hand, at a polluted site in Shanghai, China, the average formation rate of $1.3 \mathrm{~nm}$ clusters was observed to be $188 \mathrm{~cm}^{-3} \mathrm{~s}^{-1}$ (Xiao et al., 2015). Thus, it seems that the formation rates of sub-3nm clusters are higher in San Pietro Capofiume than in a clean boreal forest environment, but they are still lower than at a polluted urban site. This indicates that high background aerosol concentrations do not necessarily inhibit the formation of sub-3nm clusters if the concentrations of precursor vapors are high enough. The median condensation sink in San Pietro Capofiume was $1.1 \times 10^{-2} \mathrm{~s}^{-1}$ during the measurement period. In boreal forest, Finland, the typical condensation sink on NPF event days was observed to be about $2 \times 10^{-3} \mathrm{~s}^{-1}$ (Dal Maso et al., 2005; Kulmala et al., 2013), and in Shanghai, China, $6 \times 10^{-2} \mathrm{~s}^{-1}$ (Xiao et al., 2015).

The median formation rates of $1.6 \mathrm{~nm}$ positive and negative ions $\left(0.19\right.$ and $\left.0.06 \mathrm{~cm}^{-3} \mathrm{~s}^{-1}\right)$ were 2 orders of magnitude lower than the formation rate of $1.6 \mathrm{~nm}$ total clusters (Table 2). In addition, the median formation rates of $2 \mathrm{~nm}$ positive ions $\left(0.12 \mathrm{~cm}^{-3} \mathrm{~s}^{-1}\right)$ and negative ions $\left(0.08 \mathrm{~cm}^{-3} \mathrm{~s}^{-1}\right)$ were 1 order of magnitude lower than the formation rate of $2 \mathrm{~nm}$ total clusters. Thus, neutral pathways seem to dominate particle formation in San Pietro Capofiume. These results are consistent with the earlier observa- 

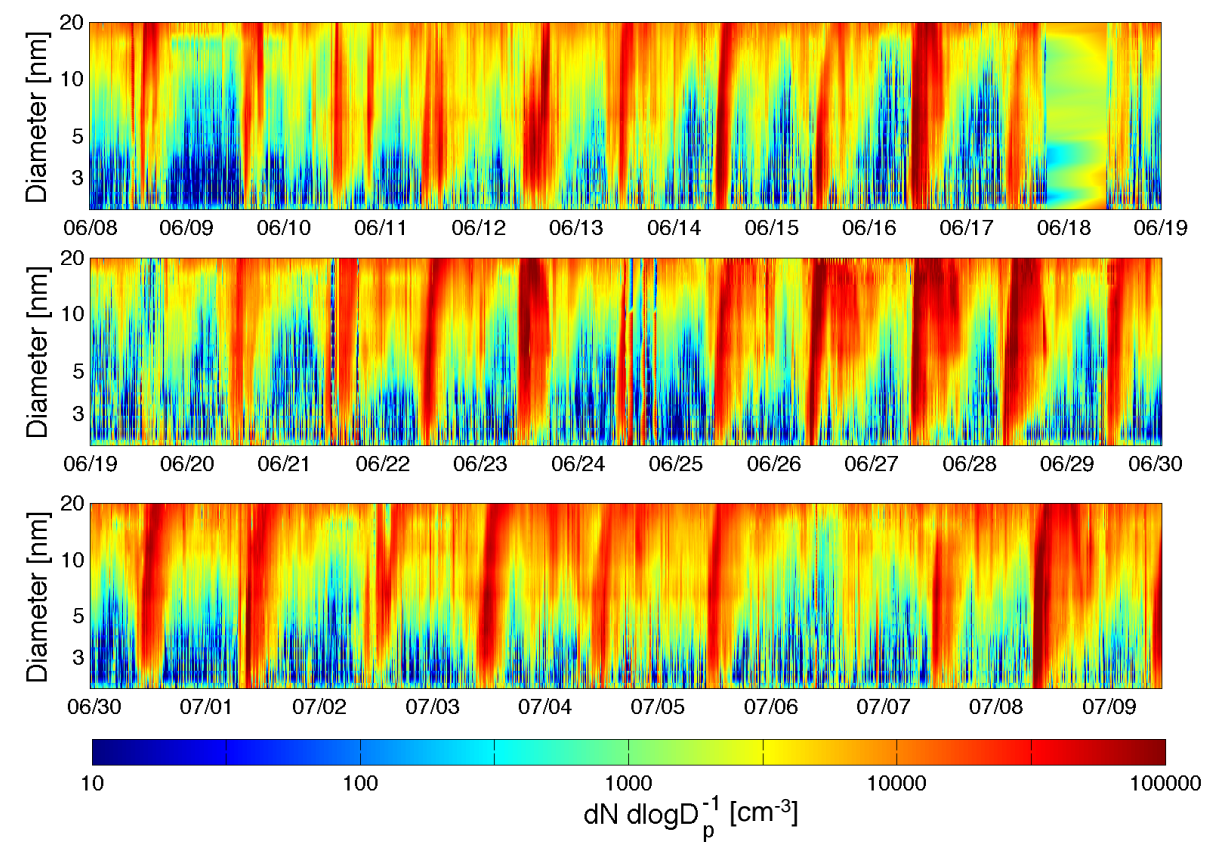

Figure 4. Time series of particle size distribution measured with the NAIS during 8 June-9 July 2012 in San Pietro Capofiume.

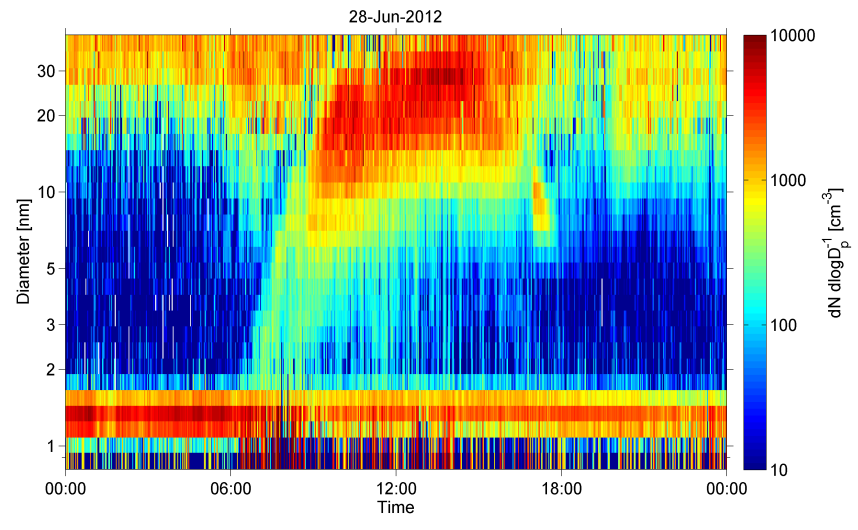

Figure 5. The size distribution of positive ions on a typical new particle formation event day at the San Pietro Capofiume station (28 June 2012).

tions from boreal forest in Finland and at a high-altitude site in France, where the formation rate of $1.5 \mathrm{~nm}$ total clusters was found to clearly exceed the formation rate of $1.5 \mathrm{~nm}$ ions (Kulmala et al., 2013; Rose et al., 2015). Manninen et al. (2010) reported slightly lower values for the median formation rates of $2 \mathrm{~nm}$ ions $\left(0.06 \mathrm{~cm}^{-3} \mathrm{~s}^{-1}\right.$ for both polarities) based on their BSMA measurements in San Pietro Capofiume. Note that the lower formation rate of $1.6 \mathrm{~nm}$ negative ions than positive ions in our measurements is mainly due to the lowered sensitivity of negative polarity of the NAIS to detect $1.5-1.8 \mathrm{~nm}$ ions.

To further investigate the contribution of ions to particle formation, we calculated the ion-induced nucleation fraction for each NPF event by dividing the ion formation rate by the total formation rate. The median ion-induced nucleation fraction was $0.7 \%$ at $1.6 \mathrm{~nm}$ and $3.0 \%$ at $2 \mathrm{~nm}$. When the contribution of ion-ion recombination is also taken into account, the total ion-mediated nucleation fraction becomes $0.8 \%$ at $1.6 \mathrm{~nm}$ and $3.7 \%$ at $2 \mathrm{~nm}$. This further demonstrates that ions have only a minor contribution to the formation of sub- $3 \mathrm{~nm}$ clusters in San Pietro Capofiume. The higher ion-induced nucleation fraction at $2 \mathrm{~nm}$ than at $1.6 \mathrm{~nm}$ suggests that ions at $2 \mathrm{~nm}$ may be formed by coagulation between small ions and neutral clusters. In previous studies the ion-induced nucleation fraction has been observed to be typically low, less than $10 \%$, in the continental boundary layer (Iida et al., 2006; Manninen et al., 2010).

\subsection{Diurnal variation of cluster concentrations and formation rates}

Figure 6 shows the median diurnal variation of the concentrations of neutral clusters, charged clusters and recombination products on NPF event days and on the only non-event day. In addition, the variation of PBL height is presented. The concentrations of neutral $1.5-1.8$ and $1.8-3.0 \mathrm{~nm}$ clusters were high throughout the day on NPF event days and on the non-event day. On NPF event days the neutral cluster concentrations had maxima around 09:00, which could not be observed on the non-event day. The concentration maximum occurred slightly earlier in the size bin of $1.5-1.8 \mathrm{~nm}$ than in the larger, $1.8-3 \mathrm{~nm}$ size bin. The daytime maximum on NPF event days can also be detected in the concentrations of ions and recombination product in the size bin of 

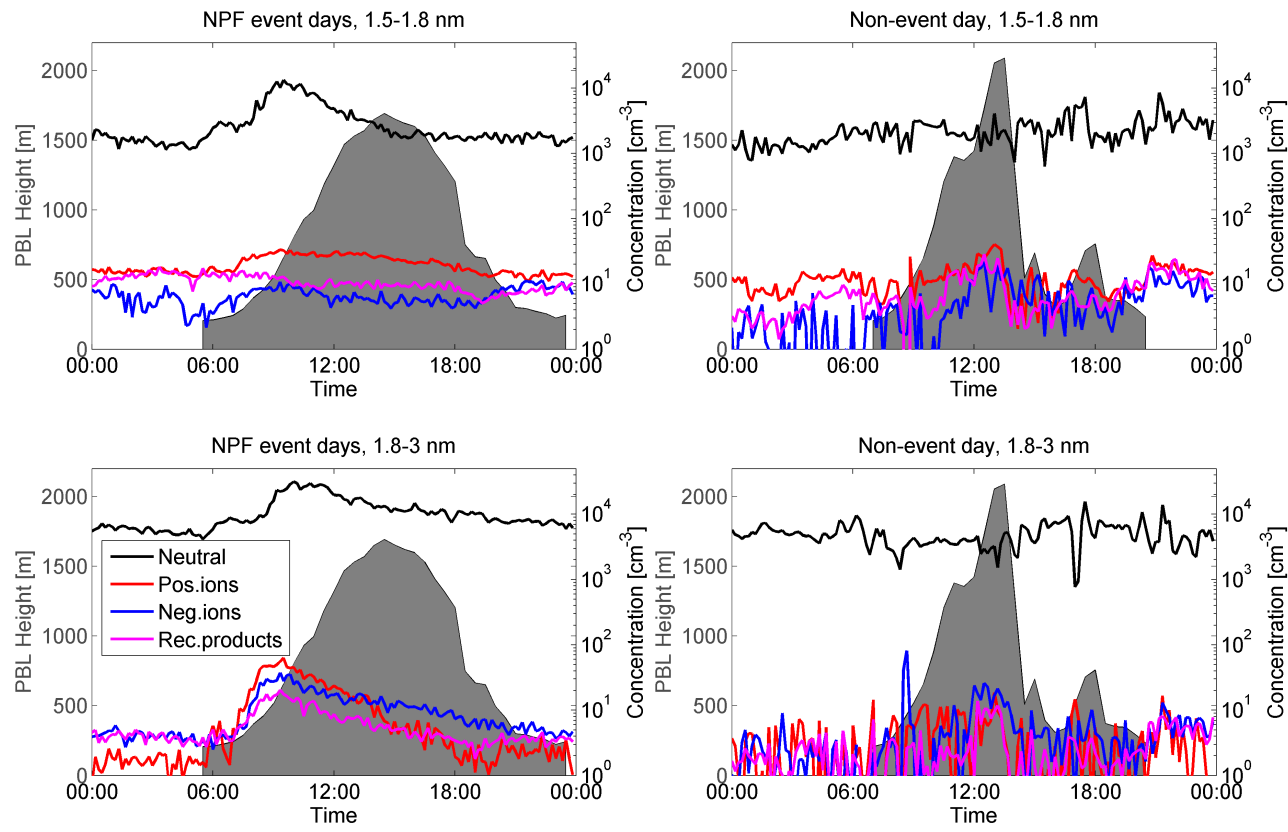

Figure 6. The median diurnal variation of the concentrations of neutral clusters (black line), positive ions (red line), negative ions (blue line) and recombination products (magenta line) on NPF event days and on the only non-event day (6 July 2012). In addition, the PBL height is shown in grey. Time is UTC $+1 \mathrm{~h}$.

$1.8-3.0 \mathrm{~nm}$. Nevertheless, the peak ion concentrations were about 3 orders of magnitude lower than those of neutral clusters. In the smaller size bin $(1.5-1.8 \mathrm{~nm})$ these maxima were not as clear. The reason for this is that small ions are continuously formed in the atmosphere as a result of ionization of air molecules, while larger ions are usually present only during NPF events (e.g., Hirsikko et al., 2011). The observed diurnal cycle of the cluster concentrations is generally similar as in the earlier observations made in boreal forest, Finland (Kulmala et al., 2013), and at urban sites in the United States and China (Yu et al., 2014, 2015; Xiao et al., 2015).

To study the contribution of ions to cluster concentrations, we also examined the median diurnal variation of the fraction of ions of all clusters on NPF event days (Fig. 7). The ion fraction in the size bin of $1.5-1.8 \mathrm{~nm}$ varied between 0.3 and $2 \%$. The lowest values were obtained slightly after 09:00, which is due to the strong increase in the neutral cluster concentration during NPF events (Fig. 6). In the size bin of $1.8-3 \mathrm{~nm}$, the ion fraction was very low (about $0.2 \%$ ) most of the time, but peaked before 09:00, reaching 0.5\%. This is caused by the fact that the concentration of ions in the size bin of $1.8-3 \mathrm{~nm}$ started to increase earlier on NPF event days than the concentration of neutral clusters in the same size bin (Fig. 6). The earlier formation of charged than neutral clusters has previously been observed at several European measurement sites (Manninen et al., 2010; Gonser et al., 2014). One possible explanation for this is the enhancement of activation of clusters in the presence of charge (e.g., Yu and Turco, 2000; Winkler et al., 2008), which al-

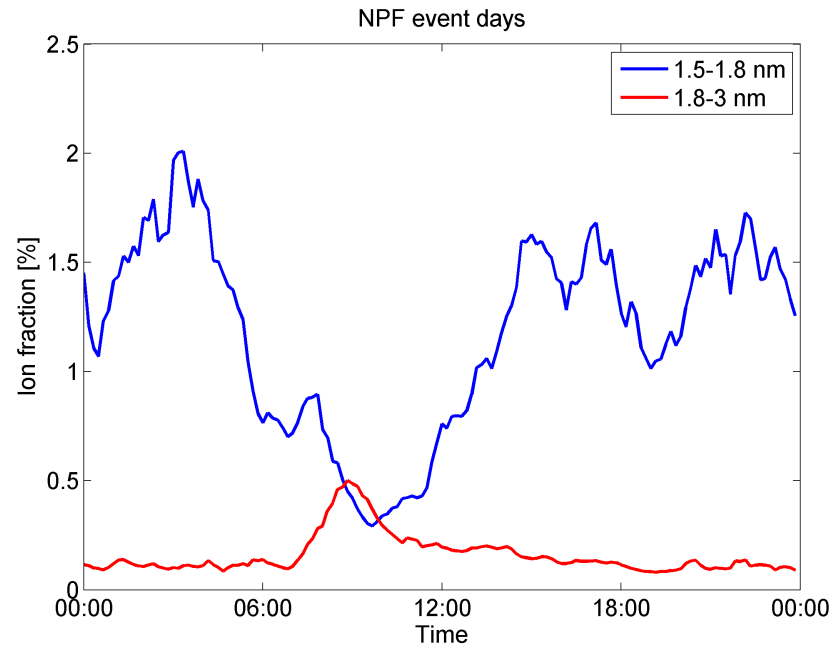

Figure 7. The median diurnal variation of the fraction of ions of all clusters in the size bins of $1.5-1.8 \mathrm{~nm}$ (blue line) and $1.8-3.0 \mathrm{~nm}$ (red line) on NPF event days. Time is UTC $+1 \mathrm{~h}$.

lows charged clusters to activate earlier than neutral clusters when the concentration of low-volatile vapors increases in the morning. This may indicate that ion-mediated nucleation pathways could be more significant in the conditions with low precursors vapor concentrations.

In Fig. 8 the median diurnal variations of particle formation rates are presented together with the PBL height for NPF event days and for the only non-event day. The formation rate 


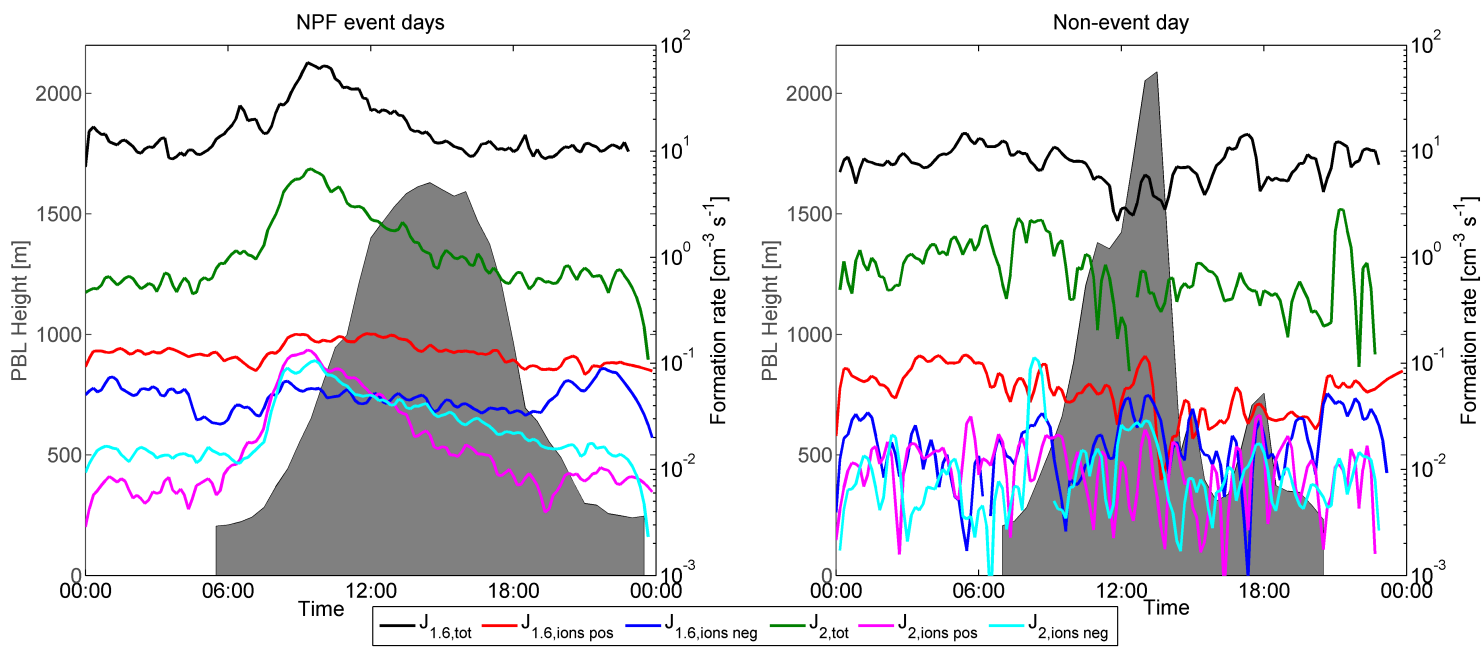

Figure 8. The median diurnal variation of the cluster formation rates at 1.6 and $2 \mathrm{~nm}$ on NPF event days and on the only non-event day (6 July 2012). The PBL height is shown in grey. In the subscripts, numbers refer to the size of the cluster in nanometers, and "tot" refers to total clusters, "pos" to positive ions and "neg" to negative ions. Time is UTC $+1 \mathrm{~h}$.

of $1.6 \mathrm{~nm}$ total clusters varied between 8 and $68 \mathrm{~cm}^{-3} \mathrm{~s}^{-1}$ on NPF event days, reaching the highest values around 09:00. On the non-event day the formation rate was lower, varying between 2 and $14 \mathrm{~cm}^{-3} \mathrm{~s}^{-1}$. Similarly, the formation rate of $2 \mathrm{~nm}$ clusters had a maximum of $7 \mathrm{~cm}^{-3} \mathrm{~s}^{-1}$ on NPF event days, and on the non-event day, it varied between 0.1 and $3 \mathrm{~cm}^{-3} \mathrm{~s}^{-1}$. The formation rates of ions were clearly lower than the total formation rates at both sizes. The maximum formation rate of $1.6 \mathrm{~nm}$ ions on NPF event days was $0.19 \mathrm{~cm}^{-3} \mathrm{~s}^{-1}$ for positive ions and $0.09 \mathrm{~cm}^{-3} \mathrm{~s}^{-1}$ for negative ions. At $2 \mathrm{~nm}$, the corresponding maximum formation rate was $0.13 \mathrm{~cm}^{-3} \mathrm{~s}^{-1}$ for positive ions and $0.11 \mathrm{~cm}^{-3} \mathrm{~s}^{-1}$ for negative ions. On the non-event day the ion formation rates were even lower than on event days. Overall, these results suggest that sub-3nm clusters are formed continuously, also outside NPF events. Furthermore, as concluded already above, neutral nucleation mechanisms seem to dominate in San Pietro Capofiume. Our results support earlier observations obtained in field measurements in boreal forest by Kulmala et al. (2013).

When comparing the diurnal variations of cluster concentrations and their formation rates with the diurnal cycle of PBL height and other meteorological parameters, similarities can be found. At the same time that the concentrations and formation rates of clusters started to increase in the morning of NPF event days, after 07:00, the PBL height also started to increase. Furthermore, at this time, radiation, temperature and $\mathrm{SO}_{2}$ concentration had already started to rise from their low nighttime values and, reversely, $\mathrm{RH}$ and condensation sink were decreasing (Fig. 2). This indicates that the sunrise can be important for the formation of atmospheric clusters due to several processes. Firstly, the buildup of PBL, induced by the heating of solar radiation, dilutes the back- ground aerosol concentration and thus reduces the condensation sink. Furthermore, the mixing of the boundary layer increases the concentration of $\mathrm{SO}_{2}$, which is oxidized to sulfuric acid. Solar radiation also triggers the photochemical production of other low-volatile precursor vapors, which may participate in the formation of clusters. Finally, increasing temperature also lowers RH. On the other hand, it needs to be noted that the formation of sub-2nm clusters was observed to take place continuously, also at night (see Fig. 8). Thus, the formation of the smallest clusters also seems to occur without solar radiation, which indicates that they may be formed, for example, by the low-volatile vapors produced in the ozonolysis of organic vapors (Ehn et al., 2014; Jokinen et al., 2014).

\subsection{Effect of sulfuric acid concentration and condensation sink on cluster concentrations}

San Pietro Capofiume is located in the industrialized Po Valley, with many emission sources for anthropogenic pollutants. According to Sogacheva et al. (2007), more than $40 \%$ of $\mathrm{SO}_{2}$ emissions over the Po Valley can be observed at the San Pietro Capofiume station. $\mathrm{SO}_{2}$ is a precursor for sulfuric acid that is known to be a key compound in atmospheric cluster formation (e.g., Weber et al., 1997; Sipilä et al., 2010; Kirkby et al., 2011). To investigate the importance of sulfuric acid for cluster formation in San Pietro Capofiume, we studied the correlation between the concentrations of neutral and charged clusters and sulfuric acid proxy. Furthermore, to see how the concentrations of large background aerosol particles affect cluster concentrations, the correlation between cluster concentrations and condensation sink was examined.

In agreement with earlier studies, the sub- $3 \mathrm{~nm}$ cluster concentrations correlated positively with sulfuric acid proxy, indicating that sulfuric acid possibly participates in the cluster 

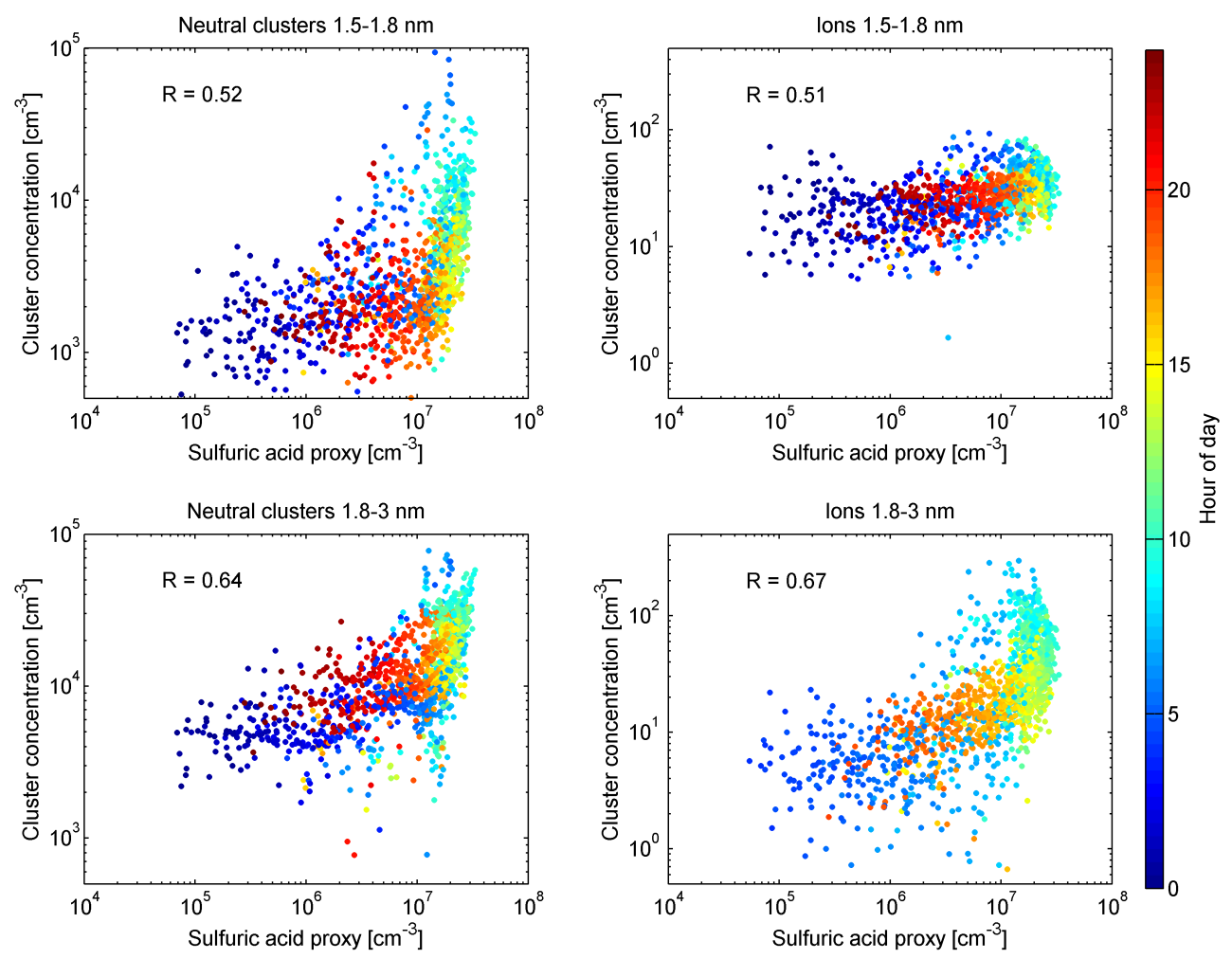

Figure 9. The correlation between the neutral and charged 1.5-1.8 and 1.8-3.0 nm clusters and sulfuric acid proxy. The color bar shows the hour of the day. The correlation coefficients $(R)$ are presented in the figures.

formation in San Pietro Capofiume (Fig. 9). For both neutral and charged clusters, the positive correlation was stronger in the size bin of $1.8-3 \mathrm{~nm}(R=0.64$ for neutral clusters and $R=0.67$ for ions) than in the size bin of $1.5-1.8 \mathrm{~nm}$ ( $R=0.52$ for neutral clusters and $R=0.51$ for ions). This is in accordance with Kulmala et al. (2013), who observed that the smallest, sub- $1.7 \mathrm{~nm}$ clusters correlated with sulfuric acid less strongly than larger clusters.

The relation between the sub-3nm cluster concentrations and condensation sink is presented in Fig. 10. It seems that the concentration of neutral clusters does not have a negative correlation with condensation sink as one would expect. This indicates that in San Pietro Capofiume, the formation of neutral clusters may, at least partly, be linked to anthropogenic emissions, with high concentrations of low-volatile precursor vapors, but also high condensation sink. Furthermore, ions had a negative correlation with the condensation sink, especially in the size bin of $1.5-1.8 \mathrm{~nm}(R=-0.56)$. In the size bin of $1.8-3 \mathrm{~nm}$ the negative correlation was weaker $(R=-0.33)$. We also investigated the correlation between the cluster concentrations and the ratio of sulfuric acid proxy to condensation sink. The correlation coefficients obtained between this ratio and the neutral cluster concentrations were slightly lower than between neutral clusters and only sulfuric acid $(R=0.51$ in the size bin of $1.5-1.8 \mathrm{~nm}$ and $R=0.62$ in the size bin of $1.8-3 \mathrm{~nm}$ ). On the other hand, for ions the correlation coefficients were slightly higher in this case ( $R=0.57$ in the size bin of $1.5-1.8 \mathrm{~nm}$ and $R=0.69$ in the size bin of $1.8-3 \mathrm{~nm}$ ).

\subsection{Effect of air mass origin}

By using back-trajectory analysis, we investigated how the air mass origin affects the sub-3nm cluster concentrations, and their precursors and sinks in San Pietro Capofiume. Figure 11 illustrates the air mass arrival directions and their relation to the total concentration of $1.8-3.0 \mathrm{~nm}$ clusters, sulfuric acid proxy and condensation sink in San Pietro Capofiume around midday (between 10:00 and 14:00). A clear majority of air masses arrived at San Pietro Capofiume from northeastern to eastern directions and from the southwest during the measurement campaign. When air masses came from northeastern to eastern directions, the sub-3nm cluster concentrations were high $\left(>3 \times 10^{4} \mathrm{~cm}^{-3}\right)$ most of the time. When air masses originated from the southwest, lower concentrations were more frequent. Moreover, the southwestern direction was often related to high condensation sink $\left(>1.2 \times 10^{-2} \mathrm{~s}^{-1}\right)$. On the other hand, high values of condensation sink were observed also when air masses came from the northeast. For sulfuric acid proxy, there was no clear difference between the northeastern and southwestern 

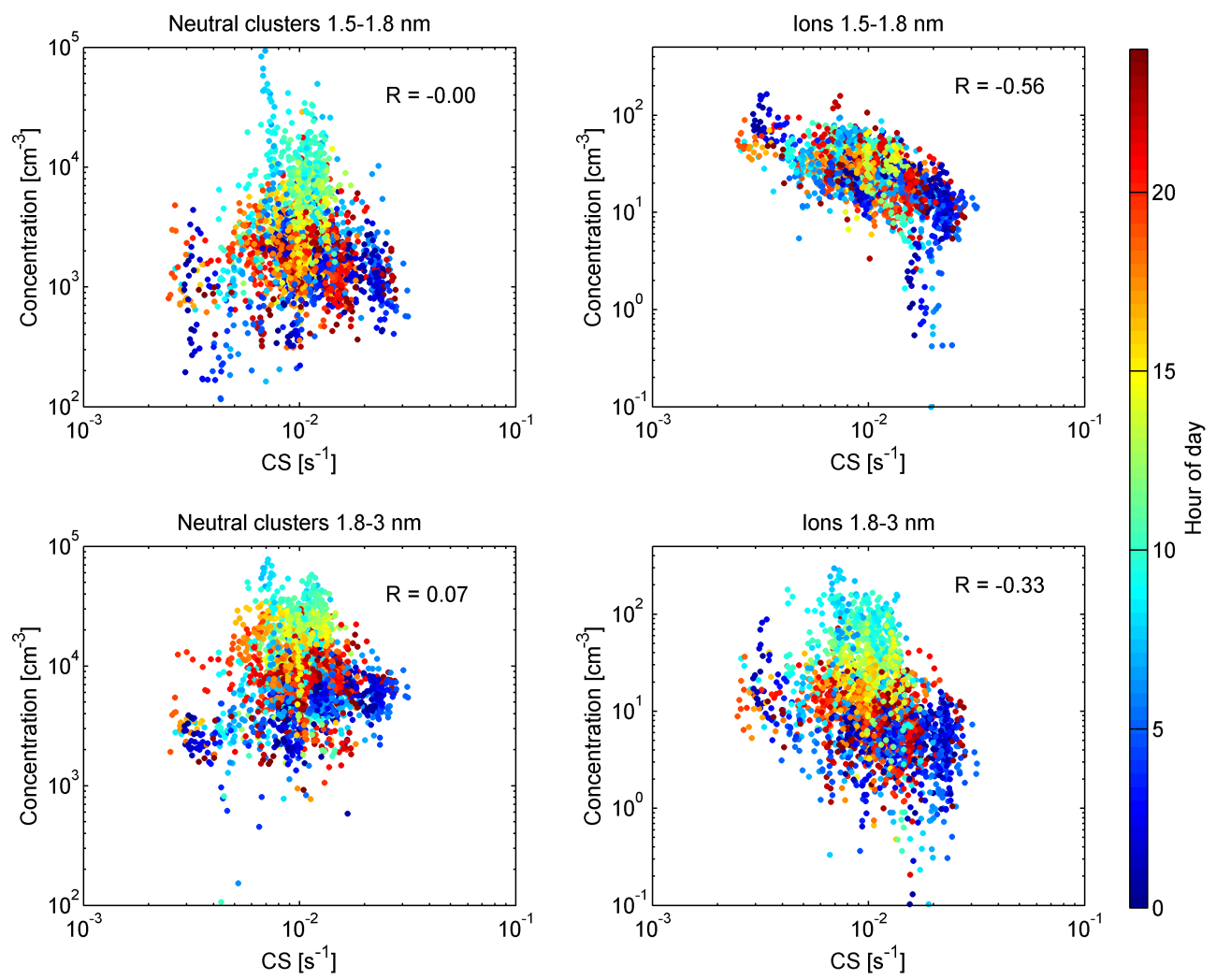

Figure 10. The correlation between the neutral and charged 1.5-1.8 and 1.8-3.0 nm clusters and condensation sink (CS). The color bar shows the hour of the day. The correlation coefficients $(R)$ are presented in the figures.

directions, but high concentrations $\left(>2.4 \times 10^{7} \mathrm{~cm}^{-3}\right)$ were linked to both of these directions.

All in all, it seems that the northeastern direction was more favorable for the formation of sub-3nm clusters than the southwestern direction during our measurement campaign. In previous studies, air masses related to particle formation have also been observed to arrive to San Pietro Capofiume mostly from eastern directions (Hamed et al., 2007; Sogacheva et al., 2007). Furthermore, Hamed et al. (2007) reported that in all seasons except summer, the eastern directions were associated with the lower value of condensation sink than the western directions. In summer, they did not observe a clear difference in condensation sink between eastern and western air masses. This is in agreement with our results which do not show significantly lower condensation sink related to the northwestern direction than the southwestern direction. Thus, it seems that during our measurement campaign, the precursor vapors of the clusters and large background aerosol particles, which act as a sink for clusters, may have originated from the same sources. This is consistent with the fact that no negative correlation was found between neutral sub-3nm clusters and condensation sink, as discussed in Sect. 3.5. The possible sources of background aerosol particles and precursor vapors include anthropogenic emissions from power plants and industrial areas in the Po
Valley, ship traffic in the Adriatic Sea, and long-range transport from central and eastern Europe (see Fig. 1) (Hamed et al., 2007; Sogacheva et al., 2007).

\section{Conclusions}

A high concentration of sub- $3 \mathrm{~nm}$ clusters was observed in the San Pietro Capofiume measurement site during the PEGASOS campaign (7 June-9 July 2012). The majority of clusters were electrically neutral. The observed sub-3nm cluster concentrations were of the same order of magnitude as at polluted sites in China (Xiao et al., 2015; Yu et al., 2015), and higher than in clean boreal forest in Finland (Kulmala et al., 2013) and at urban sites in the United States (Yu et al., 2014).

New particle formation (NPF) events were observed during the measurement period very frequently, on $86 \%$ of the days. The particle formation rates during events were higher than in a clean boreal forest environment but lower than at a highly polluted urban site (Kulmala et al., 2013; Xiao et al., 2015). Furthermore, the median formation rates of ions were clearly lower than the formation rates of total clusters at all sizes. This indicates that neutral pathways dominate the sub$3 \mathrm{~nm}$ cluster formation in San Pietro Capofiume, similarly as in boreal forest (Kulmala et al., 2013). The median condensation sink during the measurement period was relatively high, 

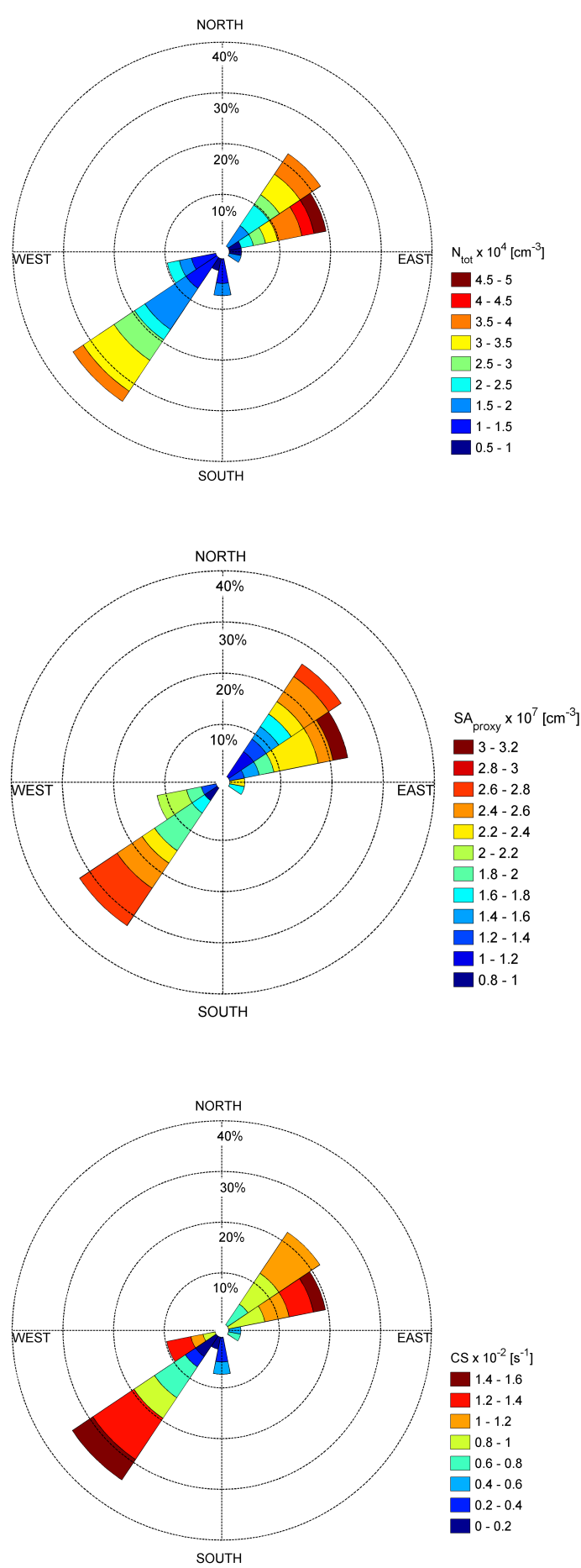

Figure 11. Air mass arrival directions and their relation to the total concentration of $1.8-3.0 \mathrm{~nm}$ clusters $\left(\mathrm{N}_{\text {tot }}\right)$, sulfuric acid proxy (SA proxy) and condensation sink (CS) in San Pietro Capofiume around midday (between 10:00 and 14:00). The length of the sectors illustrates how frequently an air mass trajectory arrived from that direction. The color of the sectors shows the value of the measured variable in San Pietro Capofiume at the arrival time of the trajectory. which demonstrates that high background aerosol concentrations do not necessarily inhibit the formation of sub-3nm clusters.

The neutral cluster concentrations were found to have maxima in the mornings of NPF event days, which were absent on the non-event day. Still, the formation of the smallest clusters was observed to take place continuously, also outside NPF events. The increase in the cluster concentration in the morning took place simultaneously with the buildup of the planetary boundary layer (PBL). In addition, radiation, temperature and $\mathrm{SO}_{2}$ concentration were rising and condensation sink and RH were declining at that time. Thus, the changes in the local meteorological conditions triggered by the sunrise in the morning may be important drivers of cluster formation at the San Pietro Capofiume station.

The sub-3nm cluster concentrations were observed to have a positive correlation with sulfuric acid proxy. This suggests that sulfuric acid may have an important role in the formation of sub-3nm clusters in San Pietro Capofiume, as has also been observed at other measurement sites (Kulmala et al., 2013; Yu et al., 2014). On the other hand, it is likely that other compounds, e.g., low-volatile organic vapors, also participate in the formation of clusters. The concentration of charged clusters was found to have a negative correlation with condensation sink, while no relation between the neutral cluster concentrations and condensation sink was observed. This result, together with the back-trajectory analysis, indicates that the precursor vapors of clusters and background aerosol particles, acting as their sink, may have originated from the same sources. The potential sources include anthropogenic emissions from power plants and industrial areas in the Po Valley, maritime traffic in the Adriatic Sea, and longrange transport from central and eastern Europe (Hamed et al., 2007; Sogacheva et al., 2007).

Acknowledgements. This research was supported by the European Commission under the Framework Programme 7 (PEGASOS project, FP7-ENV-2010-265148), the European Research Council (ERC) Advanced Grant (ATM-NUCLE, 227463), and the European Union's Horizon 2020 research and innovation programme under the Marie Sklodowska-Curie grant agreement no. 656994. Support from the Academy of Finland Centre of Excellence program (project no. 1118615 and 272041) is also gratefully acknowledged.

Edited by: A. Hofzumahaus

\section{References}

Aalto, P., Hämeri, K., Becker, E.,Weber, R., Salm, J.,Mäkelä, J. M., Hoell, C., O’Dowd, C. D., Karlsson, H., Hansson, H.-C., Väkevä M., Koponen, I. K., Buzorius, G., and Kulmala, M.: Physical characterization of aerosol particles during nucleation events, Tellus, 53 B, 344-358, 2001.

Almeida, J., Schobesberger, S., Kurten, A., Ortega, I., KupiainenMäätta, O., Praplan, A., Adamov, A., Amorim, A., Bianchi, 
F., Breitenlechner, M., David, A., Dommen, J., Donahue, N., Downard, A., Dunne, E., Duplissy, J., Ehrhart, S., Flagan, R., Franchin, A., Guida, R., Hakala, J., Hansel, A., Heinritzi, M., Henschel, H., Jokinen, T., Junninen, H., Kajos, M., Kangasluoma, J., Keskinen, H., Kupc, A., Kurten, T., Kvashin, A., Laaksonen, A., Lehtipalo, K., Leiminger, M., Leppä, J., Loukonen, V., Makhmutov, V., Mathot, S., McGrath, M., Nieminen, T., Olenius, T., Onnela, A., Petaja, T., Riccobono, F., Riipinen, I., Rissanen, M., Rondo, L., Ruuskanen, T., Santos, F., Sarnela, N., Schallhart, S., Schnitzhofer, R., Seinfeld, J., Simon, M., Sipila, M., Stozhkov, Y., Stratmann, F., Tome, A., Trostl, J., Tsagkogeorgas, G., Vaattovaara, P., Viisanen, Y., Virtanen, A., Vrtala, A., Wagner, P., Weingartner, E., Wex, H., Williamson, C., Wimmer, D., Ye, P., Yli-Juuti, T., Carslaw, K., Kulmala, M., Curtius, J., Baltensperger, U., Worsnop, D., Vehkamäki, H., and Kirkby, J.: Molecular understanding of sulphuric acid-amine particle nucleation in the atmosphere, Nature, 502, 359-363, doi:10.1038/nature12663, 2013.

Angelini, A. and Gobbi, G. P.: Some remarks about lidar data preprocessing and different implementations of the gradient method for determining the aerosol layers, Annals Geophys., 57, A0218, doi:10.4401/ag-6408, 2014.

Boy, M. and Kulmala, M.: Nucleation events in the continental boundary layer: Influence of physical and meteorological parameters, Atmos. Chem. Phys., 2, 1-16, doi:10.5194/acp-2-1-2002, 2002.

Dal Maso, M., Kulmala, M., Riipinen, I., Wagner, R., Hussein, T., Aalto, P. P., and Lehtinen, K. E. J.: Formation and growth of fresh atmospheric aerosols: Eight years of aerosol size distribution data from SMEAR II, Hyytiälä, Finland, Boreal Environ. Res., 10, 323-336, 2005.

Di Giuseppe, F., Riccio, A., Caporaso, L., Bonafè, G., Gobbi, G. P., and Angelini, F.: Automatic detection of atmospheric boundary layer height using ceilometer backscatter data assisted by a boundary layer model, Q. J. Roy. Meteor. Soc., 138, 649-663, doi:10.1002/qj.964, 2012.

Draxler, R. R. and Rolph, G. D.: HYSPLIT (HYbrid SingleParticle Lagrangian Integrated Trajectory), model access via NOAA ARL READY Website, NOAA Air Resources Laboratory, Silver Spring, MD, available at: http://www.arl.noaa.gov/ ready/hysplit4.html (last access: 13 January 2015).

Ehn, M., Thornton, J. A., Kleist, E., Sipilä, M., Junninen, H., Pullinen, I., Springer, M., Rubach, F., Tillmann, R., Lee, B., LopezHilfiker, F., Andres, S., Acir, I.-H., Rissanen, M., Jokinen, T., Schobesberger, S., Kangasluoma, J., Kontkanen, J., Nieminen, T., Kurtén, T., Nielsen, L. B., Jørgensen, S., Kjaergaard, H. G., Canagaratna, M., Dal Maso, M., Berndt, T., Petäjä, T., Wahner, A., Kerminen, V., Kulmala, M., Worsnop, D. R., Wildt, J., and Mentel, T. F.: A large source of low-volatility secondary organic aerosol, Nature, 506, 476-479, doi:10.1038/nature13032, 2014.

Gonser, S. G., Klein, F., Birmili, W., Größ, J., Kulmala, M., Manninen, H. E., Wiedensohler, A., and Held, A.: Ion - particle interactions during particle formation and growth at a coniferous forest site in central Europe, Atmos. Chem. Phys., 14, 10547-10563, doi:10.5194/acp-14-10547-2014, 2014.

Guenther, A. B., Jiang, X., Heald, C. L., Sakulyanontvittaya, T., Duhl, T., Emmons, L. K., and Wang, X.: The Model of Emissions of Gases and Aerosols from Nature version 2.1 (MEGAN2.1): an extended and updated framework for modeling biogenic emis- sions, Geosci. Model Dev., 5, 1471-1492, doi:10.5194/gmd-51471-2012, 2012.

Hamed, A., Joutsensaari, J., Mikkonen, S., Sogacheva, L., Dal Maso, M., Kulmala, M., Cavalli, F., Fuzzi, S., Facchini, M. C., Decesari, S., Mircea, M., Lehtinen, K. E. J., and Laaksonen, A.: Nucleation and growth of new particles in Po Valley, Italy, Atmos. Chem. Phys., 7, 355-376, doi:10.5194/acp-7-355-2007, 2007.

Hamed, A., Korhonen, H., Sihto, S.-L., Joutsensaari, J., Järvinen, H., Petäjä, T., Arnold, F., Nieminen, T., Kulmala, M., Smith, J. N., Lehtinen, K. E. J., and Laaksonen, A.: The role of relative humidity in continental new particle formation, J. Geophys. Res., 116, D03202, doi:10.1029/2010JD014186, 2011.

Hirsikko, A., Laakso, L., Hõrrak, U., Aalto, P. P., Kerminen, V.M., and Kulmala, M.: Annual and size dependent variation of growth rates and ion concentrations in boreal forest, Boreal Environ. Res., 10, 357-369, 2005.

Hirsikko, A., Bergman, T., Laakso, L., Dal Maso, M., Riipinen, I., Hõrrak, U., and Kulmala, M.: Identification and classification of the formation of intermediate ions measured in boreal forest, Atmos. Chem. Phys., 7, 201-210, doi:10.5194/acp-7-201-2007, 2007.

Hirsikko, A., Nieminen, T., Gagné, S., Lehtipalo, K., Manninen, H. E., Ehn, M., Hõrrak, U., Kerminen, V.-M., Laakso, L., McMurry, P. H., Mirme, A., Mirme, S., Petäjä, T., Tammet, H., Vakkari, V., Vana, M., and Kulmala, M.: Atmospheric ions and nucleation: a review of observations, Atmos. Chem. Phys., 11, 767798, doi:10.5194/acp-11-767-2011, 2011.

Hoppel, W. A.: Theory of the electrode effect, J. Atmos. Terr. Phys., 29, 709-721, 1967.

Hoppel, W. A. and Frick, G. M.: Ion-aerosol attachment coefficients and the steady-state charge distribution on aerosols in a bipolar ion environment, Aerosol Sci. Technol., 5, 1-21, 1986.

Hyvönen, S., Junninen, H., Laakso, L., Dal Maso, M., Grönholm, T., Bonn, B., Keronen, P., Aalto, P., Hiltunen, V., Pohja, T., Launiainen, S., Hari, P., Mannila, H., and Kulmala, M.: A look at aerosol formation using data mining techniques, Atmos. Chem. Phys., 5, 3345-3356, doi:10.5194/acp-5-3345-2005, 2005.

Iida, K., Stolzenburg, M., McMurry, P. H., Dunn, M. J., Smith, J. N., Eisele, F., and Keady, P.: Contribution of ion-induced nucleation to new particle formation: Methodology and its application to atmospheric observations in Boulder, Colorado, J. Geophys. Res., 111, D23201, doi:10.1029/2006JD007167, 2006.

Jokinen, T., Sipilä, M., Richters, S., Kerminen, V.-M., Paasonen, P., Stratmann, F., Worsnop, D., Kulmala, M., Ehn, M., Herrmann, H., and Berndt, T.: Rapid Autoxidation Forms Highly Oxidized RO2 Radicals in the Atmosphere, Angwe. Chem. Internat. Ed., 53, 14596-14600, doi:10.1002/anie.201408566, 2014.

Kangasluoma, J., Junninen, H., Lehtipalo, K., Sipilä, M., Mikkilä, J., Vanhanen, J., Attoui, M.,Worsnop, D., Kulmala, M., and Petäjä, T.: Remarks on ion generation for CPC calibrations in the sub $3 \mathrm{~nm}$ size range, Aerosol Sci. Tech., 47, 556-563, doi:10.1080/02786826.2013.773393, 2013.

Kazil, J., Stier, P., Zhang, K., Quaas, J., Kinne, S., O’Donnell, D., Rast, S., Esch, M., Ferrachat, S., Lohmann, U., and Feichter, J.: Aerosol nucleation and its role for clouds and Earth's radiative forcing in the aerosol-climate model ECHAM5-HAM, Atmos. Chem. Phys., 10, 10733-10752, doi:10.5194/acp-1010733-2010, 2010. 
Kerminen, V.-M., Pirjola, L., and Kulmala, M.: How significantly does coagulational scavenging limit atmospheric particle production?, J. Geophys. Res., 125, 24119-24126, 2001.

Kirkby, J., Curtius, J., Almeida, J., Dunne, E., Duplissy, J., Ehrhart, S., Franchin, A., Gagné, S., Ickes, L., Kürten, A., Kupc, A., Metzger, A., Riccobono, F., Rondo, L., Schobesberger, S., Tsagkogeorgas, G., Wimmer, D., Amorim, A., Bianchi, F., Breitenlechner, M., David, A., Dommen, J., Downard, A., Ehn, M., Flagan, R. C., Haider, S., Hansel, A., Hauser, D., Jud, W., Junninen, H., Kreissl, F., Kvashin, A., Laaksonen, A., Lehtipalo, K., Lima, J., Lovejoy, E. R., Makhutov, V., Mathot, S., Mikkilä, J., Minginette, P., Mogo, S., Nieminen, T., Onnela, A., Pereira, A., Petäjä, T., Schnitzhofer, R., Seinfeld, J. H., Sipilä, M., Stozhkov, Y., Stratmann, F., Tome, A., Vanhanen, J., Viisanen Y., Vrtala, A., Wagner, P. E., Walther, H., Weingartner, E., Wex, H., Winkler, P. M., Carslaw, K. S., Worsnop, D. R., Baltensperger, U., and Kulmala, M.: The role of sulfuric acid, ammonia and galactic cosmic rays in atmospheric aerosol nucleation, Nature, 476, 429-433, 2011.

Kontkanen, J., Lehtinen, K. E. J., Nieminen, T., Manninen, H. E., Lehtipalo, K., Kerminen, V.-M., and Kulmala, M.: Estimating the contribution of ion-ion recombination to sub- $2 \mathrm{~nm}$ cluster concentrations from atmospheric measurements, Atmos. Chem. Phys., 13, 11391-11401, doi:10.5194/acp-13-11391-2013, 2013.

Korhonen, H., Sihto, S.-L., Kerminen, V.-M., and Lehtinen, K. E. J.: Evaluation of the accuracy of analysis tools for atmospheric new particle formation, Atmos. Chem. Phys., 11, 3051-3066, doi:10.5194/acp-11-3051-2011, 2011

Kuang, C., Chen, M., Zhao, J., Smith, J., McMurry, P. H., and Wang, J.: Size and time-resolved growth rate measurements of 1 to $5 \mathrm{~nm}$ freshly formed atmospheric nuclei, Atmos. Chem. Phys., 12, 3573-3589, doi:10.5194/acp-12-3573-2012, 2012.

Kulmala, M., Toivonen, A., Mäkelä, J. M., and Laaksonen, A.: Analysis of the growth of nucleation mode particles observed in Boreal forest, Tellus, 50B, 449-462, 1998.

Kulmala, M., Maso, M. D., Mäkelä, J. M., Pirjola, L., Väkevä, M., Aalto, P., Miikkulainen, P., Hämeri, K., and O’Dowd, C. D.: On the formation, growth and composition of nucleation mode particles, Tellus B, 53, 479-490, 2001.

Kulmala, M., Vehkamäki, H., Petäjä, T., Dal Maso, M., Lauri, A., Kerminen, V.-M., Birmili, W., and McMurry P. H.: Formation and growth rates of ultrafine atmospheric particles: A review of observations, J. Aerosol Sci., 35, 143-176, 2004a.

Kulmala, M., Kerminen, V.-M., Anttila, T., Laaksonen, A., and O'Dowd, C. D.: Organic aerosol formation via sulphate cluster activation, J. Geophys. Res., 109, 4205, doi:10.1029/2003JD003961, 2004b.

Kulmala, M., Riipinen, I., Sipila, M., Manninen, H. E., Petaja, T., Junninen, H., dal Maso, M., Mordas, G., Mirme, A., Vana, M., Hirsikko, A., Laasko, L., Harrison, R. M., Hanson, I., Leung, C., Lehtinen, K. E. J., and Kerminen, V.-M.: Toward direct measurement of atmospheric nucleation, Science, 318, 89-92, 2007.

Kulmala, M., Petäjä, T., Nieminen, T., Sipilä, M., Manninen, H. E., Lehtipalo, K., Dal Maso, M., Aalto, P. P., Junninen, H., Paasonen, P., Riipinen, I., Lehtinen, K. E. J., Laaksonen, A., and Kerminen, V.-M.: Measurement of the nucleation of atmospheric aerosol particles, Nat. Protoc., 7, 1651-1667, doi:10.1038/nprot.2012.091, 2012.

Kulmala, M., Kontkanen, J., Junninen, H., Lehtipalo, K., Manninen, H. E., Nieminen, T., Petäjä, T., Sipilä, M., Schobesberger,
S., Rantala, P., Franchin,A., Jokinen,T., Järvinen,E., Äijälä ,M., Kangasluoma, J., Hakala, J., Aalto, P. P., Paasonen, P., Mikkilä, J., Vanhanen, J., Aalto, J., Hakola, H., Makkonen, U., Ruuskanen, T., Mauldin, R. L., Duplissy, J., Vehkamäki, H., Bäck, J., Kortelainen, A., Riipinen, I., Kurtén, T., Johnston, M. V, Smith, J. N., Ehn, M., Mentel, T. F., Lehtinen, K. E. J., Laaksonen, A., Kerminen, V.-M., and Worsnop, D. R.: Direct observations of atmospheric aerosol nucleation, Science, 339, 943-946, doi:10.1126/science.1227385, 2013.

Kulmala, M., Petäjä, T., Ehn, M., Thornton, J., Sipilä, M., Worsnop, D. R., and Kerminen, V.-M.: Chemistry of atmospheric nucleation: on the recent advances on precursor characterization and atmospheric cluster composition in connection with atmospheric new particle formation, Annu. Rev. Phys. Chem., 65, 21-37, 2014.

Laakso, L., Petäjä, T., Lehtinen, K. E. J., Kulmala, M., Paatero, J., Hõrrak, U., Tammet, H., and Joutsensaari, J.: Ion production rate in a boreal forest based on ion, particle and radiation measurements, Atmos. Chem. Phys., 4, 1933-1943, doi:10.5194/acp-41933-2004, 2004.

Laaksonen, A., Hamed, A., Joutsensaari, J., Hiltunen, L., Cavalli, F., Junkermann, W., Asmi, A., Fuzzi, S., and Facchini, M. C.: Cloud condensation nucleus production from nucleation events at a highly polluted region, Geophys. Res. Lett., 32, L06812, doi:10.1029/2004GL022092, 2005.

Lehtipalo, K., Sipilä, M., Riipinen, I., Nieminen, T., and Kulmala, M.: Analysis of atmospheric neutral and charged molecular clusters in boreal forest using pulse-height CPC, Atmos. Chem. Phys., 9, 4177-4184, doi:10.5194/acp-9-4177-2009, 2009.

Lehtipalo, K., Kulmala, M., Sipilä, M., Petäjä, T., Vana, M., Ceburnis, D., Dupuy, R., and O'Dowd, C.: Nanoparticles in boreal forest and coastal environment: a comparison of observations and implications of the nucleation mechanism, Atmos. Chem. Phys., 10, 7009-7016, doi:10.5194/acp-10-7009-2010, 2010.

Makkonen, R., Asmi, A., Kerminen, V.-M., Boy, M., Arneth, A., Hari, P., and Kulmala, M.: Air pollution control and decreasing new particle formation lead to strong climate warming, Atmos. Chem. Phys., 12, 1515-1524, doi:10.5194/acp-12-15152012, 2012.

Manninen, H. E., Nieminen, T., Asmi, E., Gagné, S., Häkkinen, S., Lehtipalo, K., Aalto, P., Vana, M., Mirme, A., Mirme, S., Hõrrak, U., Plass-Dülmer, C., Stange, G., Kiss, G., Hoffer, A., Töro, N., Moerman, M., Henzing, B., de Leeuw, G., Brinkenberg, M., Kouvarakis, G. N., Bougiatioti, A., Mihalopoulos, N., O’Dowd, C., Ceburnis, D., Arneth, A., Svenningsson, B., Swietlicki, E., Tarozzi, L., Decesari, S., Facchini, M. C., Birmili, W., Sonntag, A., Wiedensohler, A., Boulon, J., Sellegri, K., Laj, P., Gysel, M., Bukowiecki, N., Weingartner, E., Wehrle, G., Laaksonen, A., Hamed, A., Joutsensaari, J., Petäjä, T., Kerminen, V.-M., and Kulmala, M.: EUCAARI ion spectrometer measurements at 12 European sites - analysis of new particle formation events, Atmos. Chem. Phys., 10, 7907-7927, doi:10.5194/acp-10-79072010, 2010.

Merikanto, J., Spracklen, D. V., Mann, G. W., Pickering, S. J., and Carslaw, K. S.: Impact of nucleation on global CCN, Atmos. Chem. Phys., 9, 8601-8616, doi:10.5194/acp-9-8601-2009, 2009.

Metzger, A., Verheggen, B., Dommen, J., Duplissy, J., Prevot, A. S., Weingartner, E., Riipinen, I., Kulmala, M., Spracklen, 
D. V., Carslaw, K. S., and Baltensperger, U.: Evidence for the role of organics in aerosol particle formation under atmospheric conditions, P. Natl. Acad. Sci. USA, 107, 6646-6651, doi:10.1073/pnas.0911330107, 2010.

Mikkonen, S., Romakkaniemi, S., Smith, J. N., Korhonen, H., Petäjä, T., Plass-Duelmer, C., Boy, M., McMurry, P. H., Lehtinen, K. E. J., Joutsensaari, J., Hamed, A., Mauldin III, R. L., Birmili, W., Spindler, G., Arnold, F., Kulmala, M., and Laaksonen, A.: A statistical proxy for sulphuric acid concentration, Atmos. Chem. Phys., 11, 11319-11334, doi:10.5194/acp-11-11319-2011, 2011.

Mirme, S. and Mirme, A.: The mathematical principles and design of the NAIS - a spectrometer for the measurement of cluster ion and nanometer aerosol size distributions, Atmos. Meas. Tech., 6, 1061-1071, doi:10.5194/amt-6-1061-2013, 2013.

Mirme, S., Mirme, A., Minikin, A., Petzold, A., Hõrrak, U., Kerminen, V.-M., and Kulmala, M.: Atmospheric sub-3 nm particles at high altitudes, Atmos. Chem. Phys., 10, 437-451, doi:10.5194/acp-10-437-2010, 2010.

Nadykto, A. B., and Yu, F: Uptake of neutral polar vapour molecules by charged clusters/particles: Enhancement due to dipole-charge interaction, J. Geophys. Res., 108, 4717, 2003.

Nieminen, T., Yli-Juuti, T., Manninen, H. E., Petäjä, T., Kerminen, V.-M., and Kulmala, M.: Technical note: New particle formation event forecasts during PEGASOS-Zeppelin Northern mission 2013 in Hyytiälä, Finland, Atmos. Chem. Phys., 15, 1238512396, doi:10.5194/acp-15-12385-2015, 2015.

Nilsson, E. D., Rannik, Ü., Kulmala, M., Buzorius, G., and O'Dowd, C.: Effects of the continental boundary layer evolution, convection, turbulence and entrainment on aerosol formation, Tellus, 53B, 441-461, 2001a.

Nilsson, E. D., Paatero, J., and Boy, M.: Effects of air masses and synoptic weather on aerosol formation in the continental boundary layer, Tellus, 53B, 462-478, 2001b.

Riccobono, F., Schobesberger, S., Scott, C. E., Dommen, J., Ortega, I. K., Rondo, L., Almeida, J., Amorim, A., Bianchi, F., Breitenlechner, M., David, A., Downard, A., Dunne, E. M., Duplissy, J., Ehrhart, S., Flagan, R. C., Franchin, A., Hansel, A., Junninen, H., Kajos, M., Keskinen, H., Kupc, A., Kürten, A., Kvashin, A. N., Laaksonen, A., Lehtipalo, K., Makhmutov, V., Mathot, S., Nieminen, T., Onnela, A., Petäjä, T., Praplan, A. P., Santos, F. D., Schallhart, S., Seinfeld, J. H., Sipilä, M., Spracklen, D. V., Stozhkov, Y., Stratmann, F., Tomé, A., Tsagkogeorgas, G., Vaattovaara, P., Viisanen, Y., Vrtala, A., Wagner, P. E., Weingartner, E., Wex, H., Wimmer, D., Carslaw, K. S., Curtius, J., Donahue, N. M., Kirkby, J., Kulmala, M., Worsnop, D. R., and Baltensperger, U.: Oxidation Products of Biogenic Emissions Contribute to Nucleation of Atmospheric Particles, Science, 344, 717-721, 2014.

Rose, C., Sellegri, K., Asmi, E., Hervo, M., Freney, E., Colomb, A., Junninen, H., Duplissy, J., Sipilä, M., Kontkanen, J., Lehtipalo, K., and Kulmala, M.: Major contribution of neutral clusters to new particle formation at the interface between the boundary layer and the free troposphere, Atmos. Chem. Phys., 15, 34133428, doi:10.5194/acp-15-3413-2015, 2015.

Schobesberger, S., Junninen, H., Bianchi, F., Lonn, G., Ehn, M., Lehtipalo, K., Dommen, J., Ehrhart, S., Ortega, I. K., Franchin, A., Nieminen, T., Riccobono, F., Hutterli, M., Duplissy, J., Almeida, J., Amorim, A., Breitenlechner, M., Downard, A. J., Dunne, E. M., Flagan, R. C., Kajos, M., Keskinen, H., Kirkby,
J., Kupc, A., Kuerten, A., Kurten, T., Laaksonen, A., Mathot, S., Onnela, A., Praplan, A. P., Rondo, L., Santos, F. D., Schallhart, S., Schnitzhofer, R., Sipila, M., Tome, A., Tsagkogeorgas, G., Vehkamaki, H., Wimmer, D., Baltensperger, U., Carslaw, K. S., Curtius, J., Hansel, A., Petaja, T., Kulmala, M., Donahue, N. M., and Worsnop, D. R.: Molecular understanding of atmospheric particle formation from sulfuric acid and large oxidized organic molecules, P. Natl. Acad. Sci. USA, 110, 17223-17228, 2013.

Sipilä, M., Berndt, T., Petäjä, T., Brus, D., Vanhanen, J., Stratmann, F., Patokoski, J., Mauldin, R. L., Hyvärinen, A.-P., Lihavainen, H., and Kulmala, M.: The role of sulfuric acid in atmospheric nucleation, Science, 327, 1243-1246, 2010.

Sogacheva, L., Hamed, A., Facchini, M. C., Kulmala, M., and Laaksonen, A.: Relation of air mass history to nucleation events in Po Valley, Italy, using back trajectories analysis, Atmos. Chem. Phys., 7, 839-853, doi:10.5194/acp-7-839-2007, 2007.

Spracklen, D. V., Carslaw, K. S., Kulmala, M., Kerminen, V.-M., Mann, G. W., and Sihto, S.-L.: The contribution of boundary layer nucleation events to total particle concentrations on regional and global scales, Atmos. Chem. Phys., 6, 5631-5648, doi:10.5194/acp-6-5631-2006, 2006.

Tammet, H. and Kulmala, M.: Simulation tool for atmospheric aerosol nucleation bursts, J. Aerosol Sci., 36, 173-196, 2005.

Vanhanen, J., Mikkilä, J., Lehtipalo, K., Sipilä, M., Manninen, H. E., Siivola, E., Petäjä, T., and Kulmala, M.: Particle size magnifier for nano-CN detection, Aerosol Sci. Tech., 45, 533-542, 2011.

Wang, M. and Penner, J. E.: Aerosol indirect forcing in a global model with particle nucleation, Atmos. Chem. Phys., 9, 239-260, doi:10.5194/acp-9-239-2009, 2009.

Weber, R. J., Marti, J. J., McMurry, P. H., Eisele, F. L., Tanner, D. J., and Jefferson, A.: Measurements of new particle formation and ultrafine particle growth rates at a clean continental site, J. Geophys. Res., 102, 4375-4385, 1997.

Wimmer, D., Lehtipalo, K., Franchin, A., Kangasluoma, J., Kreissl, F., Kürten, A., Kupc, A., Metzger, A., Mikkilä, J., Petäjä, T., Riccobono, F., Vanhanen, J., Kulmala, M., and Curtius, J.: Performance of diethylene glycol-based particle counters in the sub-3 nm size range, Atmos. Meas. Tech., 6, 1793-1804, doi:10.5194/amt-6-1793-2013, 2013.

Winkler, P. M., Steiner, G., Vrtala, A., Vehkamäki, H., Noppel, M., Lehtinen, K. E. J., Reischl, G. P., Wagner, P. E., and Kulmala, M.: Heterogeneous nucleation experiments bridging the scale from molecular ion clusters to nanoparticles, Science, 319, 1374-1377, doi:10.1126/science.1149034, 2008.

Yli-Juuti, T., Nieminen, T., Hirsikko, A., Aalto, P. P., Asmi, E., Hõrrak, U., Manninen, H. E., Patokoski, J., Dal Maso, M., Petäjä, T., Rinne, J., Kulmala, M., and Riipinen, I.: Growth rates of nucleation mode particles in Hyytiälä during 20032009: variation with particle size, season, data analysis method and ambient conditions, Atmos. Chem. Phys., 11, 12865-12886, doi:10.5194/acp-11-12865-2011, 2011.

Yu, F. and Turco, R.: Ultrafine aerosol formation via ionmediated nucleation, Geophys. Res. Lett., 27, 883-886, 2000.

Yu, F. and Turco, R.: Case studies of particle formation events observed in boreal forests: implications for nucleation mechanisms, Atmos. Chem. Phys., 8, 6085-6102, doi:10.5194/acp-86085-2008, 2008. 
Yu, F., Luo, G., Bates, T. S., Anderson, B., Clarke, A., Kapustin, V., Yantosca, R. M., Wang, Y., and Wu, S.: Spatial distributions of particle number concentrations in the global troposphere: Simulations, observations, and implications for nucleation mechanisms, J. Geophys. Res., 115, D17205, doi:10.1029/2009JD013473, 2010.

Yu, H., Kanawade, V. P., You, Y., Hallar, A. G., Mccubbin, I. B., Chirokova, G., Sedlacek, A. J., Springston, S. R., Wang, J., McGraw, R. L., Mikkila, J., and Lee, S. H.: Sub-3 nm particles observed at the coastal and continental sites in the United States, J. Geophys. Res.-Atmos., 119, doi:10.1002/2013JD020841, 2014.

Yu, H., Zhou, L. Y., Dai, L., Shen, W. C., Zheng, J., Ma, Y., and Chen, M. D.: Nucleation and growth of sub-3 nm particles in the polluted urban atmosphere of a megacity in China, Atmos. Chem. Phys. Discuss., 15, 18653-18690, doi:10.5194/acpd-1518653-2015, 2015.
Xiao, S., Wang, M. Y., Yao, L., Kulmala, M., Zhou, B., Yang, X., Chen, J. M., Wang, D. F., Fu, Q. Y., Worsnop, D. R., and Wang, L.: Strong atmospheric new particle formation in winter in urban Shanghai, China, Atmos. Chem. Phys., 15, 1769-1781, doi:10.5194/acp-15-1769-2015, 2015.

Zhang, R., Khalizov, A., Wang, L., Hu, M., and Xu, W.: Nucleation and Growth of Nanoparticles in the Atmosphere, Chem. Rev., 112, 1957-2011, 2012. 